\title{
The Archaeology and History of the Spanish Governor's Palace Park
}

Anne A. Fox

Follow this and additional works at: https://scholarworks.sfasu.edu/ita

Part of the American Material Culture Commons, Archaeological Anthropology Commons, Environmental Studies Commons, Other American Studies Commons, Other Arts and Humanities Commons, Other History of Art, Architecture, and Archaeology Commons, and the United States History Commons

Tell us how this article helped you.

This Article is brought to you for free and open access by the Center for Regional Heritage Research at SFA ScholarWorks. It has been accepted for inclusion in Index of Texas Archaeology: Open Access Gray Literature from the Lone Star State by an authorized editor of SFA ScholarWorks. For more information, please contact cdsscholarworks@sfasu.edu. 


\section{The Archaeology and History of the Spanish Governor's Palace Park \\ Creative Commons License \\ (c) (1) \& 8}

This work is licensed under a Creative Commons Attribution-NonCommercial 4.0 International License 


\section{THE}

\section{ARCHAEOLOGY AND HISTORY OF \\ THE SPANISH GOVERNOR'S PALACE PARK}

ANNE A. FOX

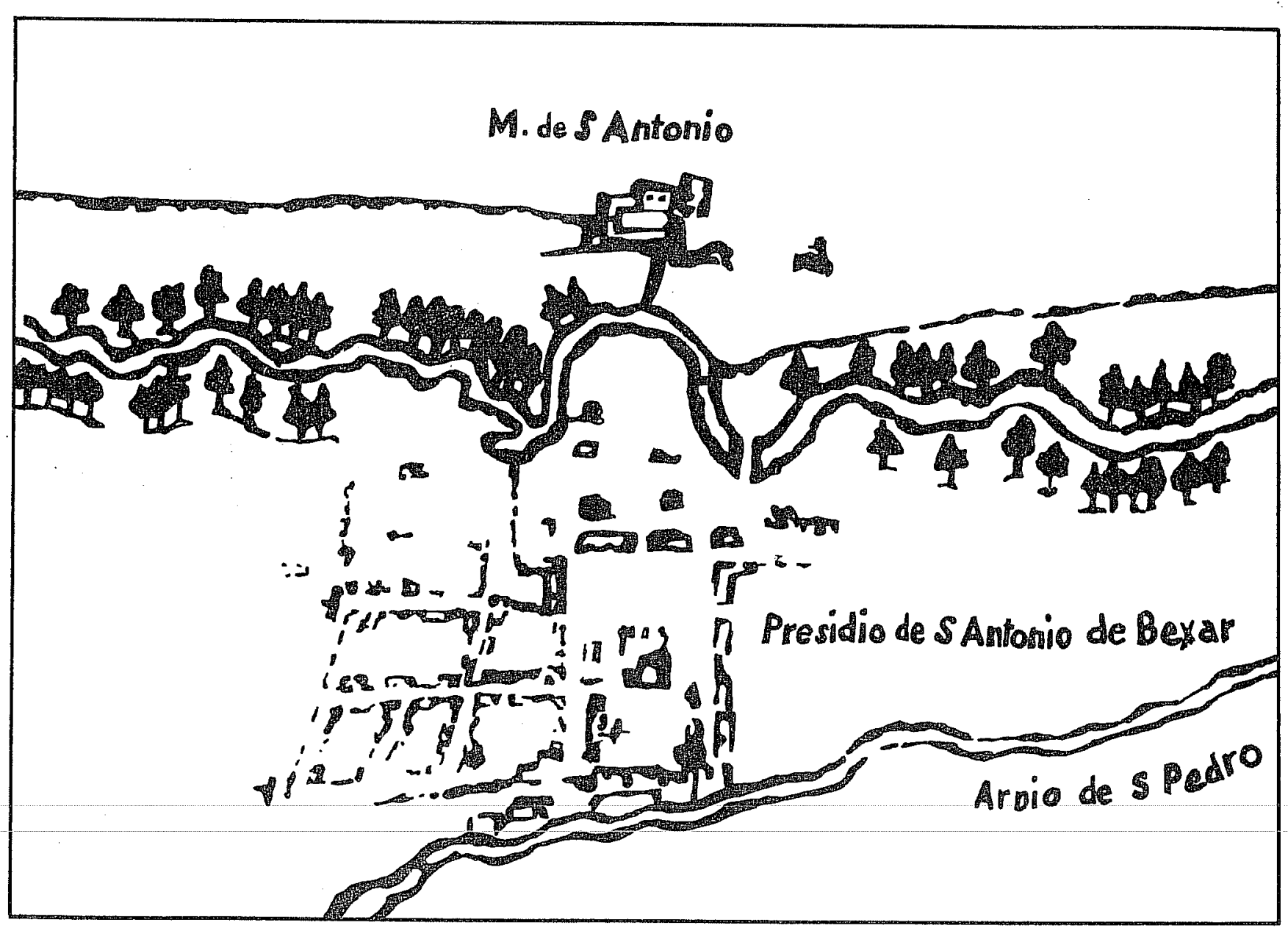

CENTER FOR ARCHAEOLOGICAL RESEARCH

THE UNIVERSITY OF TEXAS AT SAN ANTONIO

ARCHAEOLOGICAL SURVEY REPORT NO. 31 
The map on the cover is a drawing based on a map entitled "San Antonio de Bexar, mapa del presidio 1764" by Capt. Luis Antonio Menchaca. A copy of the original map is in the Daughters of the Republic Library at the Alamo. Careful examination reveals indications of a structure on the lot next to the "Governor's Palace" during the middle 18th century. 
THE ARCHAEOLOGY AND HISTORY OF

THE SPANISH-GOVERNOR'S PALLACE- PATRK

Anne A. Fox

Center for Archaeological Research

The University of Texas at San Antonio

Archaeological Survey Report No. 31

1977 


\section{LIST OF FIGURES AND TABLES}

Figures

Page

1. Villa and Presidio of San Antonio in 1767

2. Corrected Map of Military Plaza 24

3. Nineteenth Century Views of Military Plaza 25

4. The Hanging of Bob Augustine in $1861 \quad 26$

5. Nineteenth Century Views of Governor's Palace 27 Area

6. Plan and Section of Excavations at Governor's Palace Park 28

7. Photographs of Excavations 29

8. Photographs of Excavation A 30

9. Plans of Excavation A 31

10. Profiles of Excavations $A$ and $B$

11. Views of Excavations $B$ and $C$

12. Plans of Excavation $C$ and Burial in Excavation $A$

13. Artifacts from Governor's Palace Park 35

14. Artifacts from Governor's Palace Park 36

15. Artifacts from Governor's Palace Park 37

16. Artifacts from Governor's Palace Park 38

TABLE

I. Provenience of Artifacts from Colonial Deposits 39 


\section{ACKNOWLEDGMENTS}

Numerous people helped to bring this project to a successful conclusion. Dr. Thomas R. Hester, Director of the UTSA Center for Archaeological Research, served as Principal Investigator. I am grateful to Director Ronald Darner and his staff at the Parks and Recreation Department, and to employees of the Public Works Department for help in expediting the project. The staff at the Governor's Palace were particularly patient and helpful. Historic Preservation Officer Pat Osborne provided background information for the Historical research, as did Katherine McDowe 17 and Dora Guerra of the Daughters of the Republic of Texas Library, Carmen Perry of the John Peace Library at The University of Texas at San Antonio, Alice Johnson of the San Antonio Conservation Society Library, Billie Persons of the Ellen Quilian Memorial Library at the Witte Museum and Marie Berry of the San Antonio Public Library. My thanks to State Archeologist Curtis Tunnell for providing the San Fernando manuscript, and to Roger Daniels for his analys is of the skeletal remains. Architect Glenn Cook provided copies of the working drawings for the park. Monsignor Balthasar Janacek gave helpful information on burial customs and procedures.

The enthusiastic archaeological crew consisted of Nancy 0'Malley, David Swinehart and Shirley Van der Veer, with volunteer help by Lynn Highley, Wayne Jesser, W. R. Van der Veer and Dixie Wilson. 


\section{INTRODUCTION}

In the spring of 1976, test excavations were carried out by the Center for Archaeological Research of The University of Texas at San Antonio at the site of a small park to be built immediately north of the Spanish Governor's Palace on Military Plaza in downtown San Antonio. Because of its proximity to one of the original structures built by the Spanish in the early 18th century, testing was deemed necessary to determine if remains of other early structures would be disturbed by the park construction.

The testing program was administered by Dr. Thomas R. Hester. Field operations from April 26 through May 2 were directed by Anne A. Fox, Research Associate of the Center, with the help of several technical staff assistants. Standard archaeological testing procedures were used throughout the project, all soil removed from critical 18th century contexts being screened through 1/4-inch mesh. Structural remains and artifacts were fully recorded. All materials recovered were processed through the laboratory at the Center for Archaeological Research. Both before and after the excavations, considerable documentary research was necessary to establish the history of this particular site and its relation to that of the rest of 18th century San Antonio de Bexar. Results of this research are included in this report.

When the archaeological team had concluded that park construction would not appreciably damage any significant subsurface historical structures, the contractor proceeded with the work as scheduled.

\section{PREVIOUS ARCHAEOLOGICAL WORK IN THE AREA}

Unfortunately, very little archaeological work has been done in downtown San Antonio, which means that there is a paucity of information available on subsurface artifactual and structural evidence. Restoration architect Harvey P. Smith, Sr., evidently dug as deep as three to four feet to uncover what he considered to be the earliest walls of the Governor's Palace (Martin 1931:190) when that structure was rebuilt. However, no record was made of the dimensions or appearance of these footings, and little was known at that time about the uses of artifactual evidence to confirm or deny architectural findings.

In 1975 an archaeological crew from the Office of the State Archeologist conducted test excavations in the floor of San Fernando Cathedral across the Plaza (see Figure 1) in advance of a renovation project there. The report of the results of this testing has kindly been made avajlable to the author by Curtis Tunnell, State Archeologist (Fox, Clark and Scurlock 1977), and reference to these investigations will be made in the following pages.

Archaeological work was done by the Center for Archaeological Research during the summer of 1975 in the park in front of the Alamo, or Mission San Antonio de Valero (Fox, Bass and Hester 1976). Although quite a distance from Military Plaza, this excavation also provided a background of information on subsurface features which may be encountered in downtown San Antonio, 
and on the types of artifacts in use in San Antonio during various time periods.

\section{HISTORY}

The lot in question in this archaeological investigation is situated on the southwest corner of the intersection of Commerce Street (once Presidio Street) and Camaron (once Amargura), on the northwest corner of Military Plaza. A careful examination of the maps in Figures 1 and 2 will show why the history of this one small portion of downtown San Antonio is inextricably Tinked to the earliest history of the city.

Although the site of the original settlement of 1718 was near San Pedro Springs, within two years Mission San Antonio de Valero had moved south and across to the east side of the river (Habig 1968:42). The Marqués de San Miguel de Aguayo in 1721 ordered the construction of an adobe presidio on the west side opposite the mission, between the river and San Pedro Creek (Buckley 1911:55). Original7y conceived as a complex fortification with four towers and three concentric rows of structures around the central square (map in Archivo General de Indias at Sevilla), it was probably never completed beyond two towers, a surrounding wall and some wooden structures, due partly to a bad rainy season which melted adobes and hampered construction (Buckley 1911:55). Accounts vary as to the extent of this construction (see also Forresta1 1934:65) probably depending on for whom they were intended. However, it seems reasonable to infer that the comandancia and/or presidial captain's residence would have been one of the earliest substantial buildings constructed. Evidently there was such a building by 1733 when José de Urrutia became captain (Chabot 1929:30). In 1738 the cuerpo de guardia on the north side of the plaza was described as being adjacent to the residence of the governor (ibid.). The governor at that time had probably preempted the casa del capitan for himself in true military fasion.

The original keystone over the main entrance to the restored "Governor's Palace" contains the inscription "Se acabó 1749" (finished in 1749), which could refer to one particular room, or the entire bujlding. It seems possible that this merely indicates the final stage of what may have been a series of constructions and reconstructions.

The buildings around Military Plaza at that time were flat-roofed adobe or stone structures similar to the present Governor's Palace restoration. By 1767, according to the Urrutia map (Figure 1), the buildings on the west side continued across present Commerce Street and turned the corner going east, including the area in question. They were one long row of connected structures used as residences for the soldiers and their families. Governor Navarete in 1762 referred to the house of the captain, with his office, as "built of stone or rubble and mortar, and a very strong edifice" (Ramsdell 1959:122). 
Apparently the structures on the west side of the plaza were in private hands by 7780 , for the present Governor's Palace was inherited by Jose, son of Capt. Luis Antonio Menchaca, sometime after 1783 (Menchaca wi11, 1803). However, before he died, Capt. Menchaca had sold the corner to Maria Luisa Guerrero, widow of Jose Miguel Hernandez. Senora Guerrero continued to live in her chamacuero on the corner lot until she died in 1819. Her son-in-law immediately sold the corner to Ignacio Perez (Chabot 1929:37,39) who had previous $7 y$ bought the Governor's Palace property from the Menchacas in 1804, according to a deed in the Spanish Archives at the Bexar County Court House (Spanish Archives, 1804). When Perez died in 1852, his will listed the structures of the west side property in order, north to south, beginning with "the house which is called 'Of my Aunt Maria Luisa" (Chabot 1929:42).

From the mid-1800s on, the general area declined in importance in the city, and the buildings were used for the usual purposes of an older city neighborhood--bars, offices and sma 17 shops. The construction of a new courthouse and jail on the ruins of the old cuartel (barracks) of the presidio (Figures 2 and 3a) in 1850 (Chabot 1931:107) and the popularity of the Mexican market with its chili stands (Ramsde11 1959:117-118) apparently did not upgrade the neighborhood. An interesting painting by Charles Adelbert Herff in 1867 (Figure 4) shows a small adobe or stone structure on the corner lot, facing onto the plaza. The low-pitched roof sports a large green bul1, and painted across the facade is the name "Cantina del Torro Berde" (sic).

Presumably this building was soon to be torn down, as a bird's-eye view of San Antonio in 1873 shows the corner vacant (Koch 1873). Another similar view by the same artist in 1886 shows several sma11, one-story buildings on the corner lot facing north onto Commerce Street (Koch 1886 and Figure 5b). Evidently the razing of the courthouse built on the old presidio walls and the construction of a new city hall in the center of the plaza in 1890 did not influence the corner in question, as later photographs show a succession of bars, used clothing stores and vacant buildings (Figure $3 b$ ).

An upturn in the neighborhood was evident in 1928 when the City purchased the ruins of the old "Governor's Palace" and set about its restoration. The corner property was not a part of this effort; but sometime after the restoration a modern building on a concrete slat was constructed against the north wall of the Palace (King 1975), and a succession of other similar buildings was constructed (in a continous row) west of the corner where the small individual ones had stood in the 7886 Koch drawing (Sanborn Map Company). These were finally torn down in 1975 (King 1975) to make way for the proposed park.

\section{Observations}

In general, the task of the historical researcher for an archaeological project is to trace the history of the piece of ground in question and the types of construction which were built upon it. The first and most importani problem on this project was to determine which of the many eye-witness descriptions on record actualiy referred to this particular area. Although the 
name "Spanish Governor's Palace" has been attached to the building on the west side of Military Plaza for many generations, actually there were several structures in San Antonio which merited this title at various points in time. Therefore, it was necessary to determine which building was described by considering the time period involved.

The reconstructed Governor's Palace was originally built as the comandancia and casa del capitan of the presidio and primarily used for that purpose. Perhaps when it happened to be the most desirable structure in town, it was commandeered by a governor in residence in San Antonio. By 1770 when Governor Ripperdá arrived to make his headquarters in San Antonio, he moved into the casas reales across Ma in Plaza from the church (Morfi 1935:92; Figure 1), which then became the official Governor's Palace. Therefore, any later descriptions of events using the term probably refer to this structure, or possibly even to the Veramendi Palace to the north, which also seems to have been confused with the Governor's Palace in later times. For the above reasons, all descriptions referring to the Governor's Palace after 1770 have been disregarded unless they can definitely be tied to Military Plaza.

The second research problem was to determine at what time the fate of the corner lot in question was separated from that of the Governor's Palace itself. It now appears that the Spanish stone and/or adobe structure which was a continuation of the casa del capitan to the north was probably in ruins and either removed or incorporated when Maria Luisa built her chamacuero. Extensive research on this 19th century term has failed to turn up any definite meaning, except for Chabot's casual mention of "the chamaquero built of good Tumber, which Bartolo Seguin acquired from Juan Navarro in 1780" (Chabot 1929:38). Schuetz (1968:194) describes a chamacuero as "not much different than a jacal except that the rubble-filled framework was covered with hides instead of plaster," possibly taking a cue from the term cuero meaning skin or leather. It should be pointed out that the first part of the word could as readily refer to chamizal (a thatched hut) and imply a thatched roof. Whatever the translation, it seems likely that from this time there was some sort of structure on the corner lot. It was called a "house" in the Pérez will.

\section{EXCAVATIONS}

When the archaeological testing was begun, the surface was 1 ittered with broken brick, concrete chunks and other debris from the removal of the concrete slab and from other earlier buildings over whose debris the slab had been constructed. The highest point was next to the north wall of the Governor's Palace on the east side, with the surface sloping gradually to the west and to the north (Figure 6).

Test excavations consisted of four test pits and three carefully excavated areas. A permanent datum was located at the intersection of the north wall of the Governor's Palace with the surface of the sidewalk, and all elevations were measured from that point, either directly or with an alidade. 
Test 1

A preliminary shovel test was done near the northeast corner of the site to determine how much disturbance had been created by the removal of the slab. The slab, the floor of the previous building on the site, had been removed by heavy equipment immediately prior to the start of testing. The soil at this point appeared to be disturbed to a depth of approximately $30 \mathrm{~cm}$.

\section{Test 2}

A small section near the wall of the Governor's Palace was cleaned off and examined for information on the construction of the slab and any previous floors directly beneath it.

\section{Test 3 (Figure $7 b$ )}

The northwest corner of the Governor's Palace as presently reconstructed was uncovered to examine $i$ ts construction and whether an 18 th century wa 17 had extended north from this point. The existence of such a wall seemed unlikely, since it would make the resulting building too wide to correspond to the early maps. Such a wall was found extending north, but its construction was probably in the 19th century since it was too thin for a Spanish footing and was surrounded by late 19 th and early 20 th century debris and artifacts (see below). Scattered among these were occasional fragments of majolica, and burnished and lead glazed wares typical of the original Spanish deposits, indicating considerable mixing during construction.

Test 4

This was a trench perpendicular to the western edge of the property, excavated both to expose the construction of the neighboring wall for the architect's information, and to see if any evidence existed as to whether Amargura Street had ever run behind this row of buifdings, as indicated by Corner (see Figure 2). It was soon apparent that there was a deep deposit of fi7l, consisting of gravel and 7ate 19th and early 20th century artifacts over this portion of the site, corresponding to that in Test 3.

Area A

A unit was laid out across the probable location of the front wall of the presidio building as it extended north from the present Governor's Palace. The unit measured $1 \times 2 \mathrm{~m}$ and was located $1 \mathrm{~m}$ north of the Governor's Palace wall (Figure 6). At this point, the ground surface was $25 \mathrm{~cm}$ below the site datum.

At $45 \mathrm{~cm}$ (Figures $8 \mathrm{a}$ and $9 \mathrm{a}$ ) a number of chunks of concrete and reinforcing steel bars began to appear in 7 ine with the Governor's Palace wa11, the remains of the grade beam supporting the most recent building. At $47 \mathrm{~cm}$ a white 
caliche floor was found on the east side of the wall. A few centimeters deeper, a corresponding yellow caliche deposit appeared on the east side of the wall. Soil above this level was greatly disturbed and contained fragments of various building materials, glass bottles, nails and other iron objects, and mid-19th century ceramics. Just beneath this floor was a thin stratum of heavily burned material.

At $58 \mathrm{~cm}$ another white caliche floor was encountered. Between the floors on the west side of the wall line were found chert flakes, unidentifiable scraps of animal bone, sherds of Mexican-made majolica, and lead glazed and unglazed earthenwares, plus bone tempered sherds of local manufacture. A fine-screened soil sample from contact with this floor yielded numerous small chunks of lime, charcoal, flint chips and tiny animal bone fragments. On the east side of the wall the soil was sterile. At ca. $50 \mathrm{~cm}$ there was a level of yellow caliche which appeared to correspond to the floor on the inside of the structure. It was also becoming apparent that some of the wall which crossed the area was limestone, set slightly askew as if it had been disturbed when the concrete grade beam was poured (Figures $8 b$ and $9 b$ ).

In and below the second caliche floor to a depth of $70 \mathrm{~cm}$ were found more Mexican and locally made sherds and numerous chert flakes. Also found were bones of catfish, goat and domestic pig. Particularly important was the presence of several sherds of Puebla Polychrome majolica, a type apparently not made after 1725, and seldom found in San Antonio sites. On the east side of the wall at this level were occasional chert flakes and a fragment of iron.

The level excavated from 60 to $70 \mathrm{~cm}$ yielded occasional flint flakes on both sides of the wall, and revealed the fact that the wall stones ceased at this level. The concrete grade beam was set in a $2-\mathrm{cm}$ bed of sand, and the limestone sat upon dark brown, sterile soil at the same level. From 70 to $90 \mathrm{~cm}$ the soil was dark brown, homogeneous and sterile; and excavation ceased at this point (see profile in Figure 10).

An additional unit $1 \mathrm{~m} \times 2 \mathrm{~m}$ was excavated directly to the west of Area $A$ to confirm the stratigraphy and to obtain a larger artifact sample for analysis. Removal of the concrete slab had eliminated any evidence of Floor I in this unit. Directly upon Floor II at 52 to $58 \mathrm{~cm}$ were a large number of Mexican made earthenware sherds, fragments of an ornamental metal buckle and numerous animal bones which have been identified as chicken, opossum, and cow or bison. Due to lack of time, excavation was not carried any deeper.

\section{Observations}

The two caliche floors appear to have been directly associated with the front wall of the presidio building. The fact that few 18th century artifacts were found above or on Floor I suggests at least an early 19th 
century date for its use. This could also have been merely a ground surface at that time, if the structure which was the residence of Maria Luisa Guerrero was at some other location on the lot. Excavation for the later concrete grade beam could account for the break in Floor I at this point. However, from the location and size of the cantina in Herff's painting, it appears that this was a part of the original presidio building, perhaps much reconstructed, and that Señora Guerrero's house was probably built upon what was left of the old walls, and then later became the cantina. Floor II can, with some confidence, be dated to the mid-18th century, not only because of the artifacts found upon it which compare with those found in numerous other 18 th century San Antonio sites, but also because of the Puebla Polychrome majolica found beneath it. If, as is now believed, this type of earthenware was not made after 1725, it is likely that Floor II dates to the construction of this portion of the presidio, possibly as late as the 1740's or 1750's. The fact that Puebla Polychrome has been found beneath both this structure and the San Fernando church across the plaza, constructed in 1738 (Fox, Clark and Scurlock 1977) suggests that people were living on this plaza from the time the adobe presidio was built in 1721, whether or not Military Plaza was the actual site of the first presidio. If, indeed, these few remaining stones and floor are remnants of the casa del capitan and comandancia, there was little or no subsurface structure to the walls. This could explain the need for frequent reconstruction. The burned stratum just beneath floor I suggests that a fire in the building may have been the reason for reconstruction. There is a distinct possibility that the building on the corner lot was not built until after the comandancia since the only documentary evidence we have of $i$ ts existence is the Urrutia map of 1767 .

\section{Burial}

Noticeable in the surface of calice Floor II and the south wall of Pit A was a disturbance which appeared to begin just above the level of Floor I. After excavations in Pit A were finished, a small area to the south was cleared and carefully excavated to reveal a small infant burial (Figure 12). The first coffin nail was encountered at $74 \mathrm{~cm}$ and the bottom of the grave was at $90 \mathrm{~cm}$ below datum. Enough traces of wood and coffin nails were found in place to suggest the coffin's shape and size. A number of brass pins were found with the skeleton, implying that it had been wrapped in a shroud. Small fragments of blue-painted plaster were present in the grave fi11.. The burial was removed because subsequent drain construction for the park would directly disturb the interment.

The following skeletal analysis was done by physical anthropologist Roger Daniels of the Northeast School District, San Antonio.

The skeleton is almost complete. The cranial bones are considerably fragmented (evidently post-mortem) but most of the bones of the post-cranial skeleton are intact and well preserved. 
The age at death is the only information about the skeleton that can be stated with any degree of confidence. The development of the deciduous dentition indicates an age somewhere between birth and six months of age (Schour and Massler 1941). This age range is confirmed by measurements of the long bones, all of which are close (within one standard deviation) and slightly above Johnson's (1962) figures for infants newborn to six months of age. Determination of other characteristics, such as sex, on subadult bones, especially dried ones, is usually not considered reliable (Bass 1971) and was not attempted.

\section{Burial Observations}

Apparently the burial pit was dug through Floor I, which should date it sometime in the mid-19th century. Since it seems unlikely that such an interment would be made in the floor of a house, or in the Cantina del Torro Berde, the event possibly took place after the structures were razed and the lot was vacant. Numerous tiny fragments of blue-painted plaster were found only above Floor I in the excavation of Area $A$. We do know that there was a terrible cholera epidemic in San Antonio in 1866. James (1938: 46) reported there were 293 deaths. It is conceivable that a sma11 coffin could have been quietly buried during such a time of grief and confusion without attracting much notice.

Another possibility is suggested in a report by Governor Antonio Martinez in 1819:

...asking that the troops be reljeved of paying the building fees (a form of taxes) because of the scarcity of money, because the cemetery was constructed by the citizens and troops together, and also because there are many burial prices and the relatives of the deceased are forced into violation since the building tax does not cover the charges" (Taylor $1957: 396)$.

It may be that families of early 19 th century soldiers who were unable to pay burial fees were not above arranging impromptu burials. This would not have presented any problems of conscience, particulariy if the baby were stillborn and unbaptized, since such a burial would not have been allowed in a consecrated cemetery in any event (Monsignor Balthasar Janacek, personal communication).

The design of the coffin determined from placement of the nails is typical of the middle 19th century (see Schuetz 1974:30, and a painting by Gentilz in 1849 entitled "Entierro de un ángel" in KendaTt and Perry 1974:83). The presence of a carefully constructed coffin and a shroud indicates thought and loving care rather than a hasty, furtive interment. 


\section{Area B}

Pit B was laid out across the speculated back wall of the presidio building, in line with the back wall of the second room in the Governor's Palace. It measured $1 \mathrm{~m} \times 2 \mathrm{~m}$ and was located in line with Pit $A$ at $1 \mathrm{~m}$ from the Governor's Palace wall. Depths were measured from the surface at the southwest corner, $49 \mathrm{~cm}$ below the site datum.

The first $20 \mathrm{~cm}$ contained a mixture of 18 th century Mexican and local wares and 19 th century glass, metal and ceramics, plus an accumulation of building materials from previous structures on the site. Animal bones included numerous unidentifiable fragments, plus chicken, cow, goat and rat bones.

The next $50 \mathrm{~cm}$ yielded numerous artifacts dating from ca. 1860 to the 1880 s, including whole glass bottles, ironstone dishes and other mid- to late-19th century wares, both square cut and wire nails and fragments of various types of building materials. Also found were bones of cow, duck, chicken, turkey, dog or coyote, goat, fish and rat. These materials appeared to continue to an undetermined depth, and excavation was stopped.

Immediately to the east of Pit B, a $1 \mathrm{~m} \times 1 \mathrm{~m}$ pit was opened to investigate a stone wall which had shown yp at the east end of $B$, its top at approximately $38 \mathrm{~cm}$ below the southwest corner of the square.

From the ground surface to the level of the top of the wall, this pit yielded 19th century earthenwares, crockery and glass fragments. These were concentrated above the layer of caliche which capped the squares (Figure 10), and below this point the pit contained apparently undisturbed Spanish Colonial deposits in a dark grey brown soil to a depth of $160 \mathrm{~cm}$ below the surface. The wall evidently was a retaining wall built against the soil on the east side, then filled with the trash on the west side at a later date. The provenience chart and profile (Table I and Figure 10) cortain further details on stratification and individual artifact locations.

Observations

The fact that a back wall for the presidio building was not found in Area $B$ may mean that the structure was not two rooms wide at this point, or that evidence of its existence was removed by later construction on the site. The construction of a basement, which was subsequently filled with 1860 s to 1880s trash, may have eliminated the back wall. Apparently this excavation remained open for quite a period after the building over it was torn down. The 1873 koch drawing must have been made during that time (see above). It is interesting to note several varieties of rat bones present in the artifact inventories from Area B (Figure 17). According to a local citizen, after the Civil War everyone threw trash and garbage into the back yard and this, plus the grain from numerous livery stables, "harbored thousands of rats and millions of flies" (James 1938:45). 
The materials in the deep excavation in the eastward extension of Area $B$ appear to represent the earliest settlement on the site, possibly before the construction of the presidial building across this area. The presence of two distinctly early types of majolica, Puebla Polychrome, which was not made after 1725 (Snow 1965:32), and San Augustine BTue-on-White, which was made after 1730 (Goggin 1968:189), tends to confirm this supposition.

The depth of the accumulation can be attributed to the numerous floods which have afflicted the city over the years, washing in and depositing al7uvium on the site time and again (see James 1938:45, Ramsde11 1959:48, Hatcher 1935:331, Taylor 1957:535). In the middle 18th century, there was onty one other structure between the row of presidio buildings and San Pedro Creek, and nothing to impede the floodwaters (Figure 5a).

Area $C$

A pit $1 \mathrm{~m} \times 2 \mathrm{~m}$ was 1 aid out across the probable location of the front wall of the presidio building, $62 \mathrm{~m}$ from the north wa17 of the Governor's Palace. At this point the ground surface was $39 \mathrm{~cm}$ below the site datum. Excavations to $50 \mathrm{~cm}$ revealed no trace of the original colonial floors or ground surfaces still remaining. Fragments of the grade beam from the concrete slab were still in place (Figure 11). Artifacts recovered were primarily from the eariy 19 th century. 


\section{IDENTIFICATION AND DISTRIBUTION OF FAUNAL REMAINS* \\ (Number of Identified Individuals)}

Bone included in the following analys is was obtained by screening deposits through 1/4-inch mesh in Areas $A$ and $C$ and the eastern half and first level of the western half of Area B. From the nineteenth century deposits in Area $B$ and the test pits, a random sample was taken. Faunal identification was done by Billy Davidson of the Center for Archaeological Research.

\section{Species}

Unidentified fish

Lepisosteus sp. (gar)

Pylodictis olivaris (yellow catfish)

Ictalurus furcatus (blue catfish)

Micropterus sp. (black bass)

Unidentified turtle

Trionix sp. (softshell turtle)

Unidentified smal1 bird

Bovid (cow or bison)

Capra sp. (domestic goat)

Sus scrofa (domestic pig)

Gallus gallus (chicken)

Didelphis marsupialis (opossum)

Anas sp. (duck)

Meleagris gallopavo (wild turkey)

Odocoileus virginianus (white-tail deer)

Canis sp. (dog or coyote)

Sigmodon dispidus (cotton rat)

Rattus sp. (roof rat)

Rattus norvegicus (Norway rat) 18th Century Deposits 19th Century Deposits

1

6

3

2

1

1

1

1

1

12

9

1

7

1

Unidentifiable fragments

Bovid-size fragments

"Round steak" bones

Sâi-cut bones 
Observations on Faunal Recovery

Although the actual sample was limited, some interesting patterns are apparent. As noted above, the high incidence of rats in the late 19th century levels, which are generally considered disease carriers (Davis 1960:204-205), coincides with the historic record of infestation and epidemic reported in the 1860s.

Choices of animals in the diet, except for the predictable continuity of cow, goat and chicken which came with the first settlers, are interesting to note. The 18th century diet reflects quite markedly the physical restrictions imposed by the constant threat of Apache depredations, which forced citizens to rely on food close at hand during the 18th and early 19th centuries. Thus we see evidence of an emphasis on fish and turtles from the streams which ran through the town, an opossum which would have been nearby, and no evidence of hunting afield for deer or turkey.

In contrast, 19th century deposits hint at a change in emphasis away from the streams, and the freedom to hunt away from the town. The following descriptions of game available around San Antonio in the late 19th century are in Vinton James' Frontier and Pioneer Recollections (1938:47):

On December 10th, 1873, there was a sale on Military Plaza of sixty-three wagons of produce and wild game, buffalo meat, wild turkeys and deer.

On December 18th, 1876, A. Sarton, a jeweler, Dorsh, a saloon man, and Henry Elmendorf, a hardware merchant, returned from a hunt on the Hondo with 22 deer, one bear, and hundreds of wild turkeys.

On January 1st, 1876, wild turkeys sold on the steets of San Antonio for 15 and 20 cents a piece.

Of course, this also is a reflection of the difference in eating habits of a primarity Anglo population, which is apparent as welt in the ceramics and other artifacts recovered from these levels.

\section{ARTIFACTS}

Since the main purpose of the test excavations was to determine the presence or absence of early Spanish structures on the site, artifact descriptions have been limited to those found in identifiable Spanish contexts. This includes $a 11$ of Areas $A$ and $C$ and the section of Area $B$ to the east of the 19th century retaining wal1. Artifacts recovered from strictly 19th century contexts and disturbed areas are 1isted under the appropriate excavation unit in Appendix 2. A detailed study of these materials would add appreciably to our knowledge of 19th century San Antonio, but that is unfortunately beyond the scope of this report. Provenience for all artifacts and animal bones from Spanish deposits will be found in Table $I$. 
Black lace designs with blue-on-white, cup and plate. Puebla Polychrome, last half of 17th century (Goggin 1968:180) to ca. 1725 (Snow 1965:32)

(4) Figure $15 \mathrm{~b}$ and $\mathrm{c}$.

Sgraffito designs on red paste. Guanajuato (Lister and Lister 1975:42) Figure $15 d$.

olive Jar

Reddish tan paste with thin green glaze on inside of vessel. Probably Goggin's (1964:270) Middle Sty7e, 1580 to 1780 (8) Figure 74h.

Lead Glazed Utility wares

Yellow and olive green glaze, red to dark grey paste, bowls and 017 as. Sandy Paste Utility Wares (Fox 1974:56) (41) Figure 141.

Decorated Orange Ware (Fox 1974:57-58) Figure $14 i$.

Yellow, hand-modeled bowl and 011a (Fox 1974:57) (8).

Red-brown glaze on red paste. Guadalajara ware (Schuetz 1969:51) (12) Figure 14 a and $k$.

Beige paste with yellow glaze, impressed design (1) Figure $14 j$.

Unglazed Utility wares

Buff paste, wheel made bowls and ollas, some with red painted designs (see Fox, Bass and Hester 1976:67) (109).

Bone tempered, hand-modeled bowls and 011 as, one with incised design. Goliad Ware (see Fox, Bass and Hester 1976:67) (146) Figure 14 a, b, c.

Burnished wares

Burnished designs on matte surface, red paste. Red Burnished (Gilmore 1974: 63) (8) Figure $14 f$.

Burnished tan paste with red, black and yellow designs. Tonalá Polychrome (Fairbanks 1973:170) (10) Figure $14 \mathrm{e}$ and $\mathrm{g}$.

Glass

Window or mirror (18)

Brown container (4)

BTue container ( 7 )

Dark green container (4)

Aqua container (22 plus 1 whole bottle)

Clear container (8)

Lamp chimneys, $1 \mathrm{~mm}$ thick or less (3) 
Varicolored marble, $2 \mathrm{~cm}$ diameter (1)

Button, brown, 4 holes, $1 \mathrm{~cm}$ diameter (1)

Bead, $4 \mathrm{~mm}$ diameter, turquoise, translucent, donut-shaped, simple construction, tumbled (1).

\section{Meta]}

Square cut nails (8)

Wire nails (26)

Unidentifiable nails (5)

Heavy spike $7 \mathrm{~cm}$ long (7)

Bar, round stock, $1.25 \mathrm{~cm}$ diameter $\times 14 \mathrm{~cm}$ (1)

Bar, square stock $1 \mathrm{~cm}$ square $\times 6 \mathrm{~cm}$ (1)

Chain links (3) Figure 16c

Lead fragments (2)

Rivet (T)

Ornamental buckle (1) Figure 16d

Brass straight pin (1,5 more with buria1) Figure 16a

Brass disc with embossed design (1)

Brass stripping (1) Figure 16b

Chunks of unidentifiable metal (10)

\section{Building Materials}

Hand-formed brick and/or tile, ca. $3 \mathrm{~cm}$ thick, orange-pink. Common on

18th and 19th century Spanish sites (Fox, Bass and Hester 1976:77).

Yellow brick (2)

Plaster and/or mortar, some painted pastel green or blue (samples).

Concrete (samples).

Terrazzo tile (sample).

Composition tile of several colors (samples)

Burned limestone (sample).

\section{A7tered Stone}

Chert flakes and fragments (93, including 1 unifacial tool and 4 utilized fiakes) Figure $16 \mathrm{f}$ and $g$.

Quartzite flakes (4, including 1 utilized flake) Figure $16 e$.

Bone

Fragments of animal bone $(1,125)$. For species see Table I. 
Shè11

Freshwater mussel fragments (42); apparently from nearby San Antonio River.

Comments

In both the San Fernando (Fox, Clark and Scurlock 1977) and Alamo Plaza

(Fox, Bass and Hester 1976) excavations, numerous fragments of chert

resulting from the production of chipped stone artifacts were found

throughout the deposits. The same situation prevailed at this site. It

is becoming apparent that some flint working activity must have continued

among local residents throughout the Spanish colonial period. This may

reflect the need for cutting and scraping tools during severe shortages

of metal such as occurred in San Antonio during the early 1800's. Governor

Antonio Martinez repeatedly begged his superiors to send iron in order

that the cannon and small arms of the troops might be made workable

(Hatcher 1935:69, 141, 142, 146, 237), and implied that a 17 available iron

in the settlement had been melted down to make such repairs. The settlers

may have been acquainted with the technology of flint working either from

their contacts with the local Indians or from prior experience elsewhere.

Certainly the production of gun flints was practiced on the frontier when

imported flints were scarce (see Greer 1967:113 and Figure 24, and

Schuetz 1969:73 and Plate 30). Perhaps current studies on work recently completed in other areas of the city plus future work in the downtown area will add to our information in this regard. Meanwhile it should be borne in mind that the presence of chert flaking debris may not necessarily indicate Indian occupation in the San Antonio area.

\section{CONCLUSIONS}

The prime objective of the testing was to determine if any historically important structural remains would be damaged or eliminated by the park construction, which would include numerous underground trenches and concrete footings. Evidence of the earliest Spanish colonial structures on the site apparently consist of a few remnants of the front wall and two related caliche floors on the highest point in the southeast corner, as revealed in Area $A$. The surface, and in most places the subsurface, have been so thoroughly disturbed by later construction during the 19th and 20 th centuries that all other traces have been eliminated. 
APPENDIX 1

INVENTORY OF TEST PITS

Test \#3

Random Sample

\section{Ceramics}

4 majolica

3 lead glazed

1 burnished (Tonalá)

7 white earthenware, blue-painted

1 white earthenware, mocha

18 white "ironstone," "Johnson Bros.," Staffordshire ca. 1883 to present, "Cartwright/Semi-Granite," Ohio ca. 1904

5 white porcelain hotel china, "KT\&K/China" Ohio ca. 1870s

7 crockery

2 heavy, unglazed ceramic fragments

1 porcelain electric fixture marked "BRYANT-JUNIOR/2A 125V PAT D JUNE 9, 1903"

1 fragment porcelain insulator

1 glass button, opaque white

1 she 11 button

\section{Giass}

34 clear, including drinking glass base, heavy molded hexagonal base, 2 stoppers, 7 amp chimney fragments, 1 milk bottle "Dairy1and/Pasteurized," in business ca. 1931-1954.

13 aqua, including 1 Coca-Cola bottle (1923 date)

9 olive green

6 brown

1 clear glass with red painted design

1 opaque pale green

3 opaque white

1 cut glass bow 1

1 marble

40 window or mirror

Metal

26 wire nails

6 square cut nails

1 horseshoe

1 fragment wire

1 can leather dressing or polish

1 hemispherical bel1

1 metal strapping fragment

1 iron ring

1 iron washer

1 heavy bolt with nut

1 bottle cap

1 piece harness hardware

1 chunk heavy iron object 
3 fragments cast iron pipe

1 fragment lead

\section{Miscellaneous}

building materials

1 bag plaster with pale blue paint

1 fragment red asphalt tile

1 fragment terrazzo

3 fragments clay tile

1 fragment cement grout

1 fragment marble slab

1 fragment yellow brick, painted yellow over red

1 fragment tan brick

1 fragment hand-made brick/tile $2.5 \mathrm{~cm}$ thick

1 U.S. nickel, 1920

1 fragment slate pencil

2 fragments battery carbons

1 fragment leather

1 fragment roofing asphalt

1 fragment coa 1

3 fragments chert

\section{Animal Bone}

21 unidentifiable fragments

3 "round steak" bones

7 bovid size

unidentified fish--small vertebra fragment--over $101 \mathrm{bs}$. chicken--scapula, radius, 2 tibias, femur, humerus--2 adults turkey--2 humeri--2 aduits roof rat--3 pelvis fragments, femur, jaw--1 adult, 1 juvenile goat--vertebra, metatarsa 1--adult bos/bovid--2 ribs, carpal--adult

Test

Random Sample

Ceramics

1 white earthenware, spattered

2 white "ironstone" marked "Johnson Bros.," Staffordshire 1883 to present (Godden 1971:73)

1 white earthenware, dark blue glaze both sides

\section{Glass}

1 brown container

1 yellow pressed glass salt shaker

2 clear containers

1 nearly whole bottle, clear, 19th century whiskey shape

1 opaque white container

5 fragments window or mirror glass 


\author{
APPENDIX 2 \\ INVENTORY OF LATE 19TH CENTURY DEPOSITS \\ AREA B, WEST OF RETAINING WALL \\ $0-90 \mathrm{~cm}$
}

\title{
Ceramics
}

5 plain white majolica

3 blue on white majolica

1 Huejotzingo Blue on white majotica

1 Aranama Polychrome majolica

1 San Augustine Blue on white majolica

1 white glaze, possibly faience

5 lead glazed

1 black burnished

6 unglazed utility ware

5 bone tempered local ware

2 white, undecorated

7 hand-painted and/or sponged

4 mocha and/or banded ware

1 transfer

5 Tuster

3 porcelain, 2 hand-painted

7 yel1ow paste utility ware

11 Texas-made crockery

1 gin jug

122 white "ironstone china"

"Royal Stone China/Baker \& Co." W. Baker \& Co., Fentan, Staffordshire. 1839-1893 (Godden 1964:51)

"Ford Bros." The Ford City Co., Ford City, Pa. Late 19th century (Kove1 and Kovel 1971:175)

"Ironstone/China/E \& C Cha 17.....". E \& C. Challenor, Fentan, Staffordshire 1862-1891 (Godden 1964:137).

"Wood \& Son/England" Wood \& Sons, Burslem, Staffordshire 18651907 (Godden $1977: 700$ )

"Royal Warranted Best Ironstone/---CK \& Co./England." Henry A7cock \& Co., Cobridge, Staffordshire ca. 1861-1910 (Godden $1977 \cdot 52$ )

\section{G7ass}

166 clear containers, plus 4 whole bottles

68 aqua containers, plus 7 whole bottles

49 olive green containers

43 brown containers, plus 1 restorable bottle

15 opaque white containers

1 opaque green container

18 lamp chimneys

3 contemporary soda bottles

279 window or mirror glass

3 white glass buttons

1 white glass dangle with broken metal shank

1 glass marb?e 
Metat

45 square cut nails

100 wire nails

22 unidentified nails

1 screw

1 tack

8 tin cans and fragments

4 iron rods

6 iron bars

15 wire fragments

2 bolts

1 bracket

1 chain 1 ink

1 washer

1 large staple

19 cast iron pipe fragments

1 horseshoe

1 iron ring, $3^{\prime \prime}$ diameter
1 U.S. penny, 1948

1 U.S. nickel, 1889

1 U.S. quarter, 1866

2 machine parts

1 3-tined fork

1 screw cap

2 crown caps

1 brass ornamental boss

1 brass button molded over cardboard

1 brass object with stone set

1 heavy semi-circular object (scale weight fragment?)

1 4-hole button

1 brass ferrule

1 rolled lead strap

1 fragment copper

60 unidentified rusted chunks

Building Materials

20 concrete

7 terrazzo

18+ composition flooring tile fragments

4 plaster

29 red clay tile

13 hand-made brick/tile

11 red/orange brick

4 yellow brick

Miscellaneous

1 shell button

1 plastic screw top

4 battery carbons

1 bag leather shoe scraps

8 coal fragments

1 cinder

1 bag wood fragments
1 heating element of mica and copper 7 chert flakes

1 chert biface fragment

1 mussel shell fragment

Animal Bone

121 unidentifiable fragments

39 from bovid-sized animal

10 with saw marks

8 "round steak" bones

Anas sp. - at least 2 adults

Gallus gallus - at least 2 adults

Meleagris gallopavo - 1 adult

Canis sp. - juvenile dog or coyote 
Sigmodon hispidus - sub-adult

Rattus norvegicus - 3 adults, 1 juvenile Capra sp.- 1 adult, 1 juvenile Bovid - 2 adults 
Figure 1. Villa and Presidio of San Antonio in 1767, by Joseph de Urrutia.
A. Casa del Presidio
B. Casa del Capitan
C. Cuerpo de Guardia
D. Plaza de la Villa
E. Casas Reales
F. Iglesia

Copied from a photographic enlargement in the library of the San Antonio Conservation Society. The original is in the British Museum in London. 


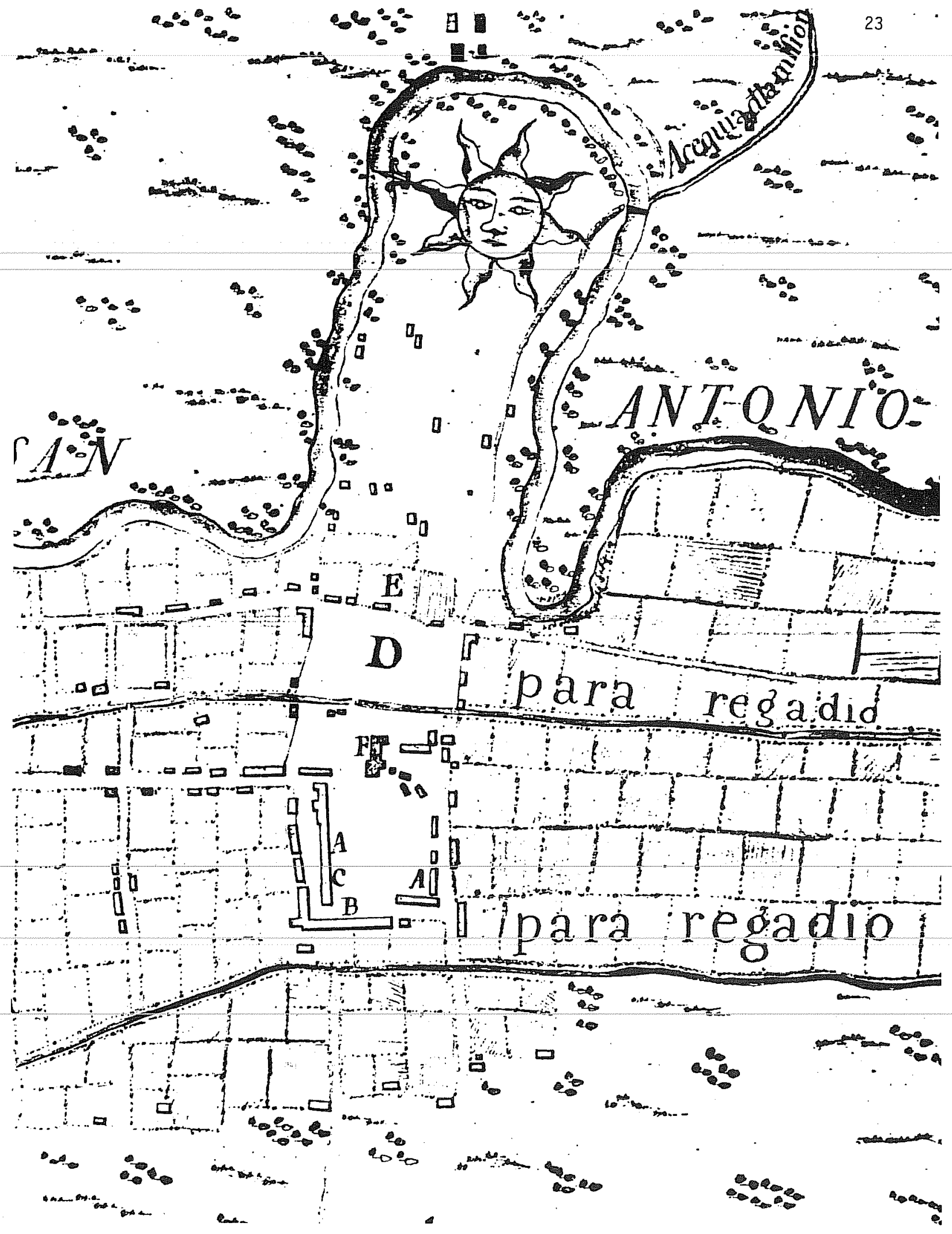


Figure 2. Corrected Map of Military Plaza. A number of maps of this area done in the 1ate 19th century and later perpetuate an error which first appears to occur in an undated map in the City Engineer's Office (Index No. 1800, File No. 6, Section No. 8). This map shows Camaron Street continuing directly south through the intersection with Commerce and running behind the Governor's Palace. Corner (1890:np) included an identical map in his book, and later authors have unwittingly used the same source. It is the opinion of the author, based upon a number of early sources and maps, that the following map is more nearly correct. 


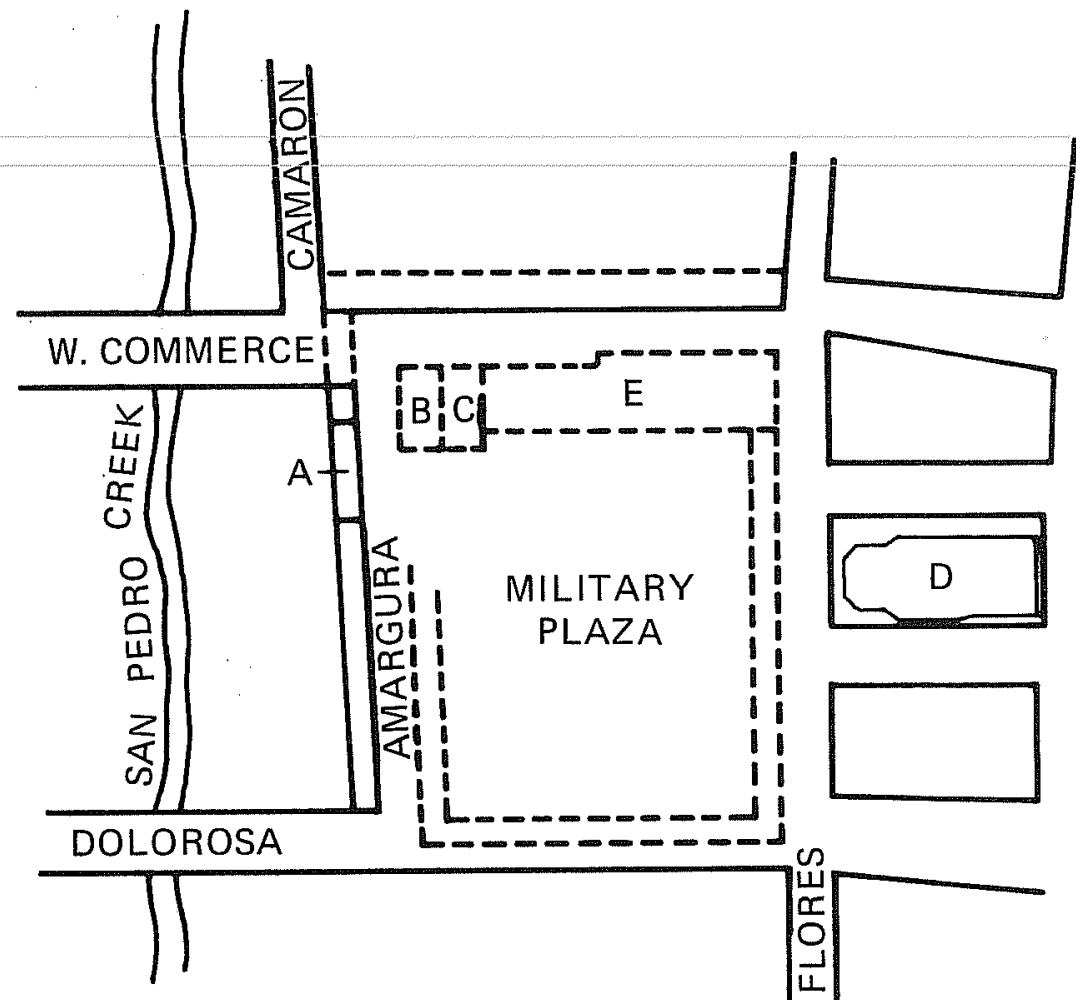

CORRECTED MAP OF MILITARY PLAZA

(A) Casa del capitan

(present "Governor's.Palace")

(B) 1850 Jail

(C) 1850 City Hall

(D) San Fernando Church

(E) Cuartel

- - Approximate wall lines of 18 th century structures 
Figure 3. Nineteenth Century Viens of Military Plaza. a, view looking northeast from the west side of the Plaza at the old Courthouse and Jail, built in 1850 on the ruins of the original cuartel and torn down when the present City Hall was built in $1890 ; b$, view of the Governor's Palace in 1927, just before its restoration. (Photographs courtesy of the Daughters of the Republic of Texas Library.) 


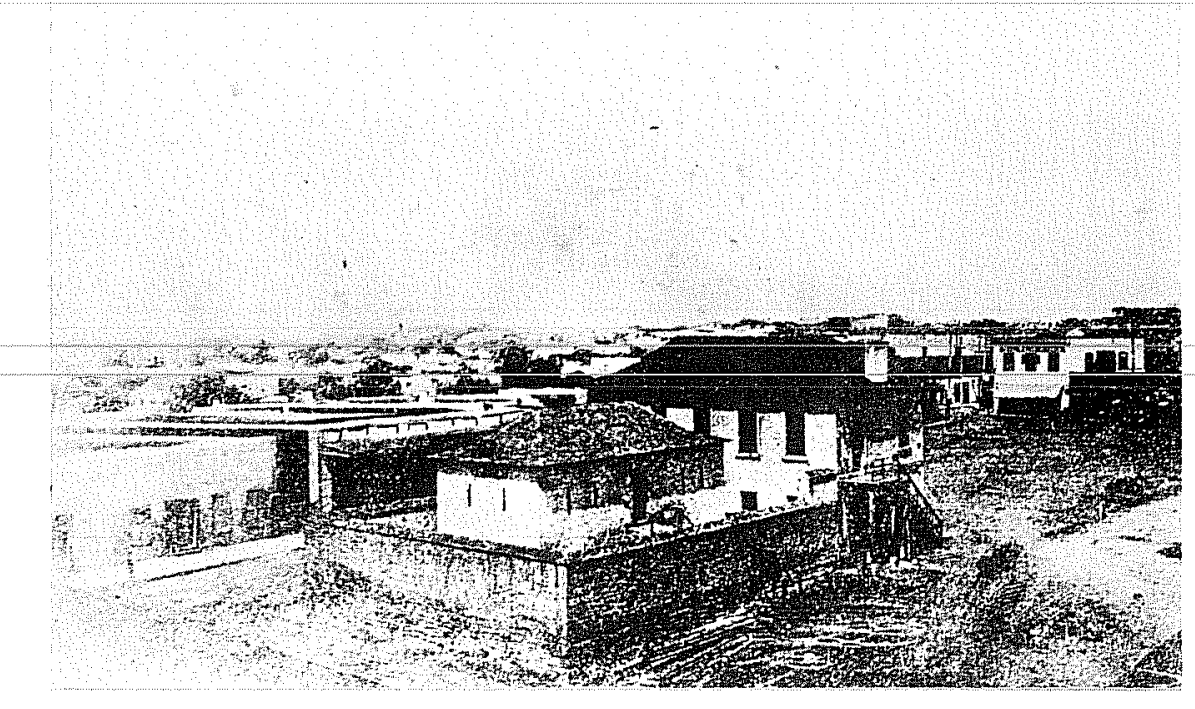

a

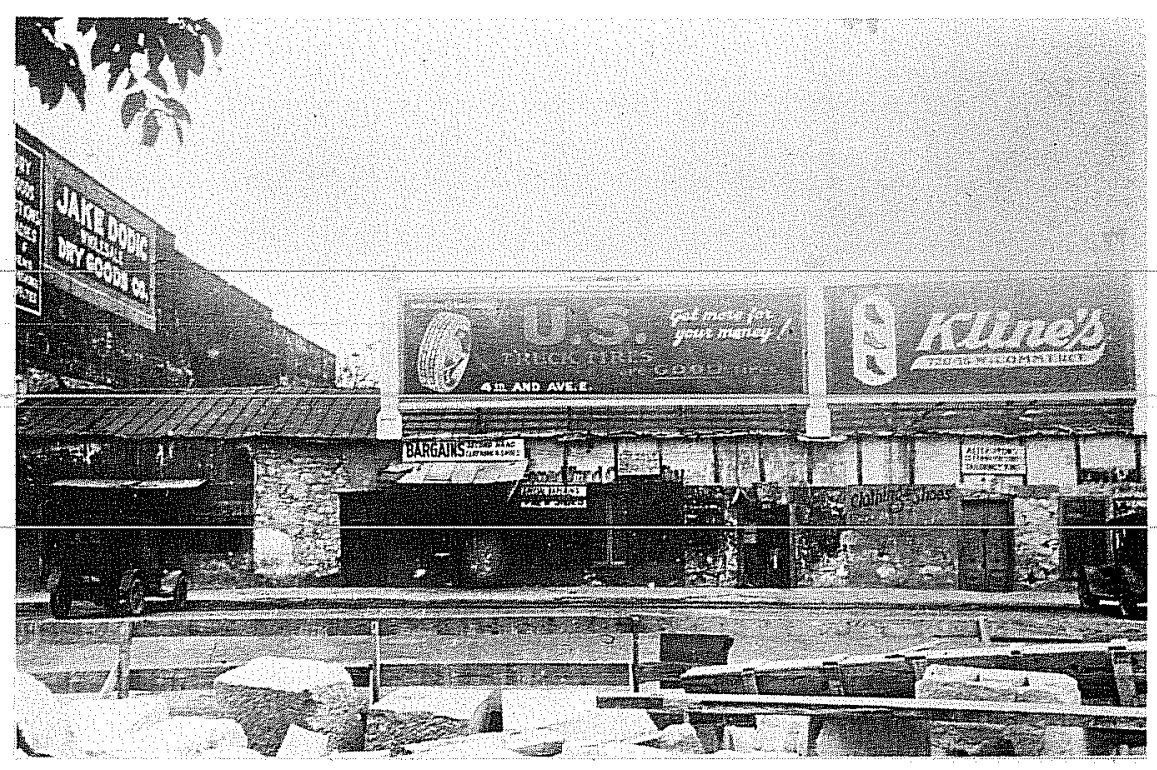

b 
Figure 4. The Hanging of Bob Augustine in 1861, done from memory by Charles Adelbert Herff 1876-1877'. Note the Cantina del Toro Berde to the right and behind the court House. Notice also the appropriately named El Palacio bar to the left rear, and farther to the left the Fandango of Madam Candelaria, a wel1-known local gathering place in the mid-19th century. The camels were passing through on the way to Camp Verde, a part of the U.S. Army's experimental Camel Corps which was abandoned soon after this date. 


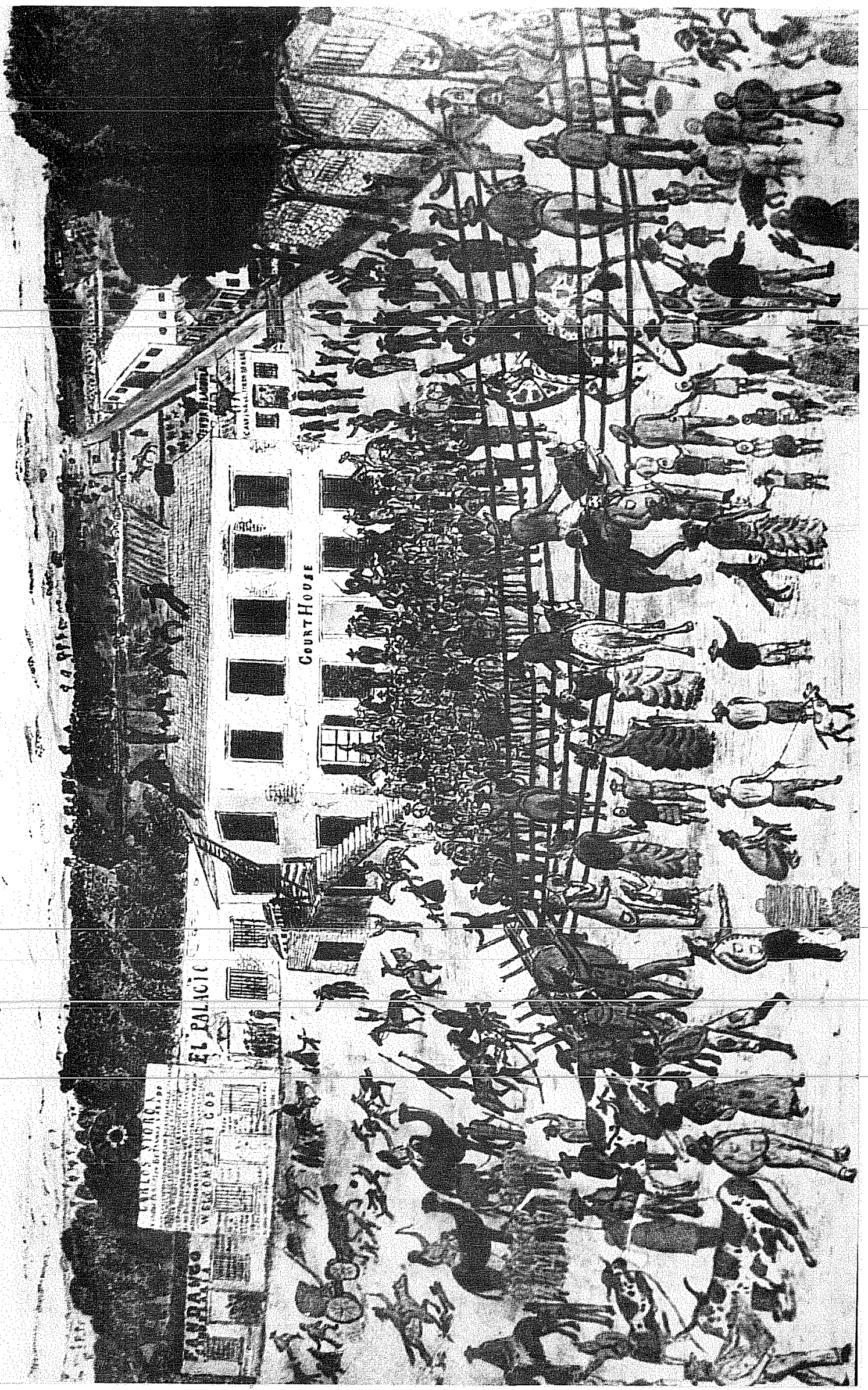


Figure 5. Nineteenth Century Views of Governor's Palace Area. a, view looking north on San Pedro Creek in the vicinity of the Governor's Palace. The bridge at the center of the picture is on Commerce Street. Every slight rise in this creek flooded the land on either side. Major floods were known to join San Pedro Creek and the San Antonio River into one large stream for brief periods, causing considerable damage in the town (Taylor 1957:535; James 1938:45); b, view looking south on Camaron Street toward the Governor's Palace in the 1880's, showing the variety of structures and roof lines present. 


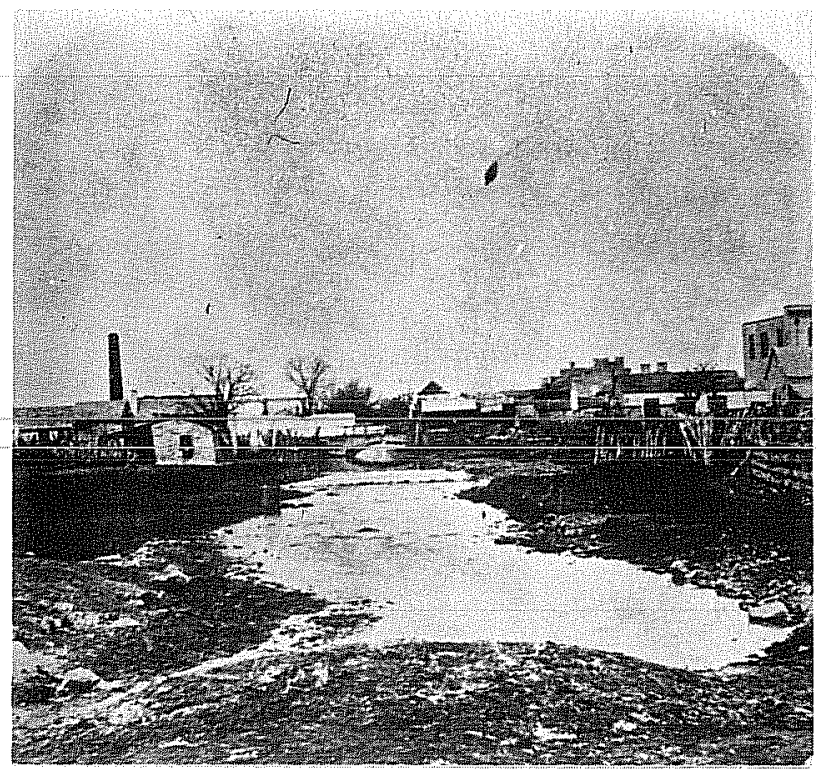

a

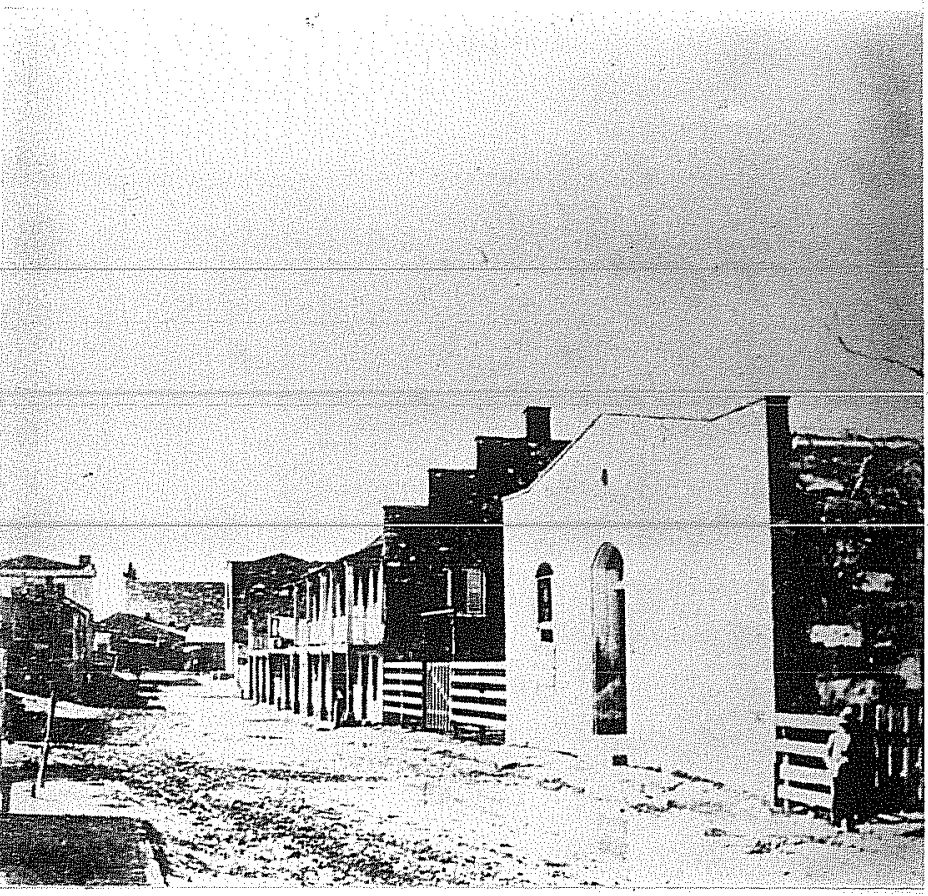

b 


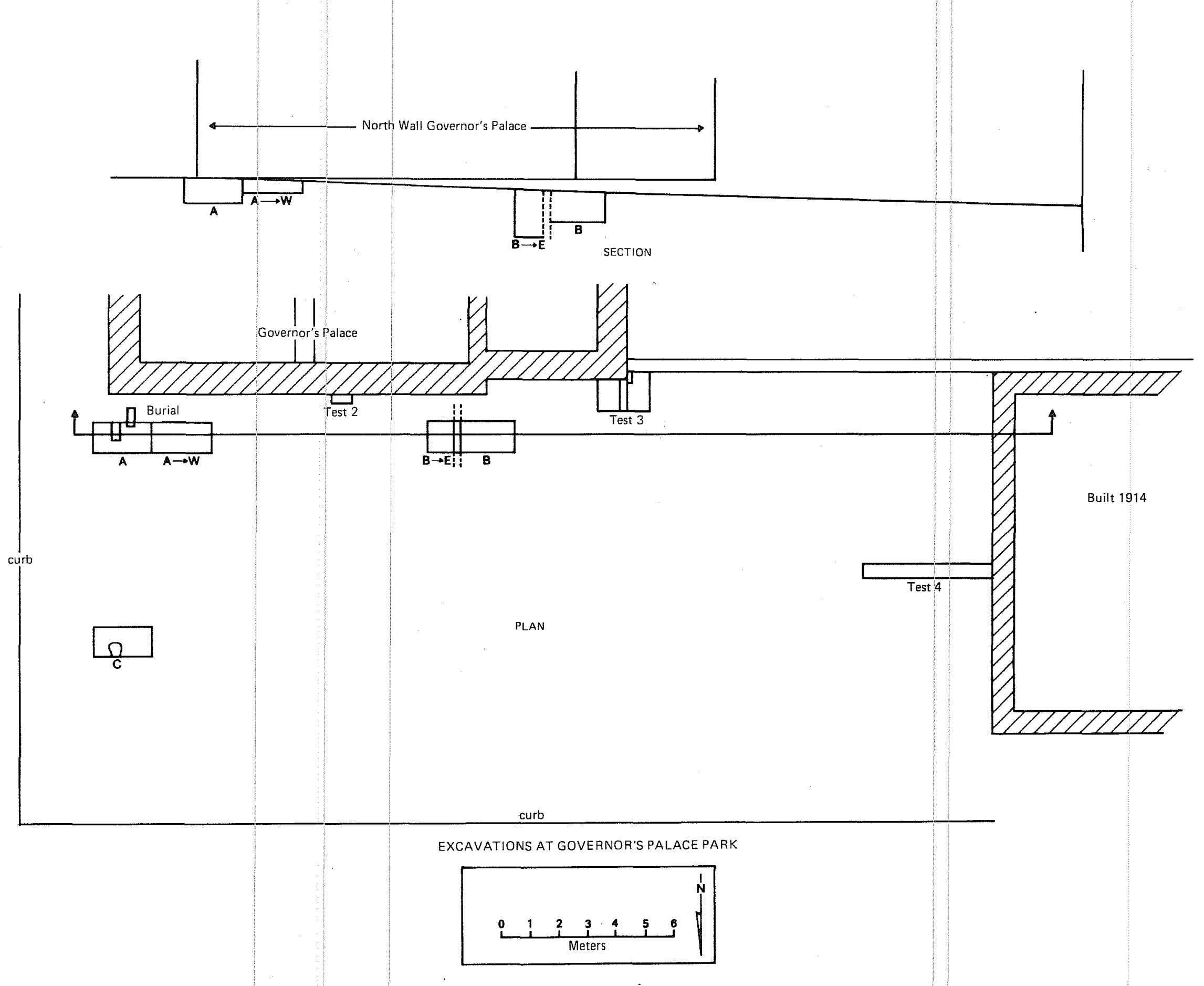

Figure 6. Plan and Section of Excavations at Governor's Palace Park. 


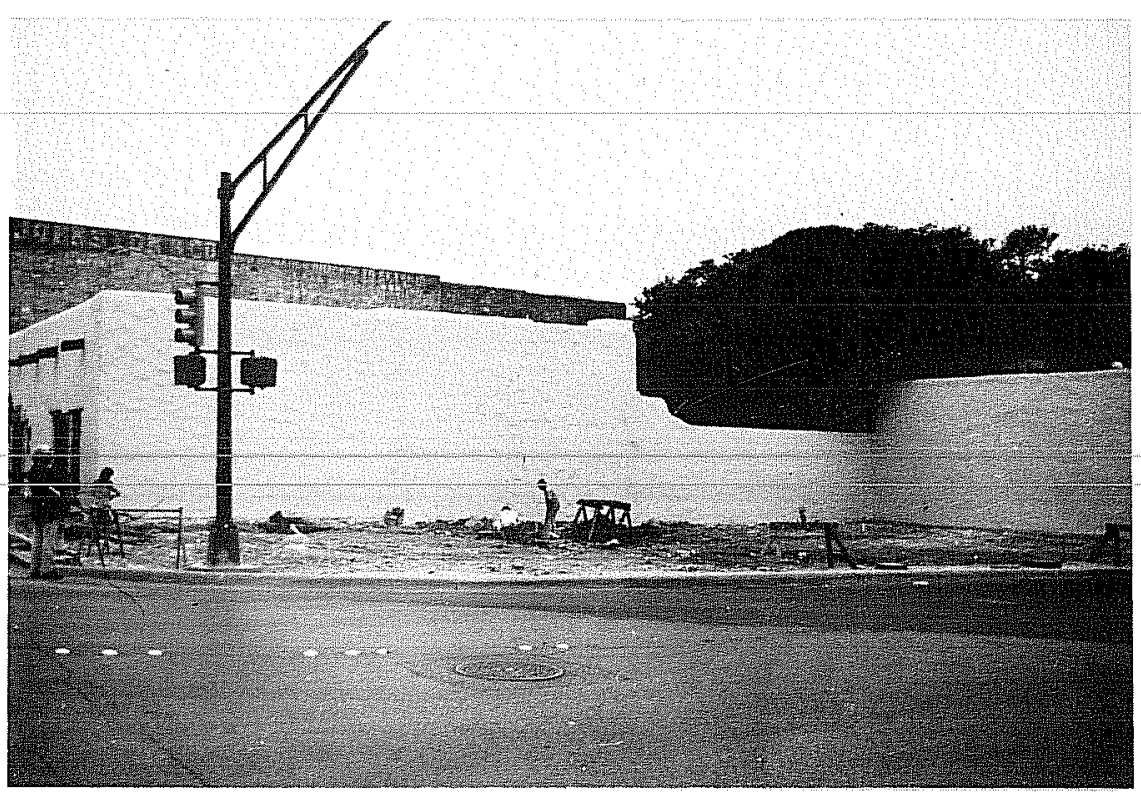

a

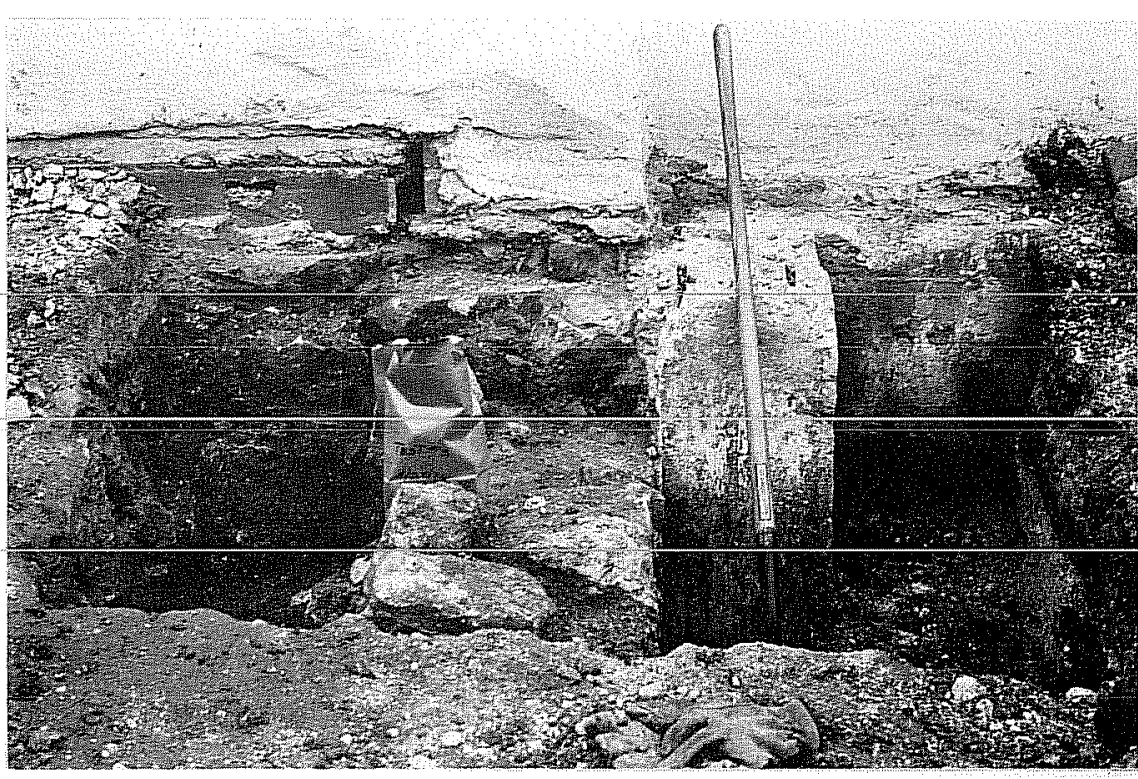

b

Figure 7. Photographs of Excavations. a, view of park area during archaeological testing, looking southwest; $b$, Test Number 3 , showing the relationship between the Governor's Palace foundation wall in the left rear, the later stone foundation wal1 and the concrete beam and pier from a 20th century structure. 


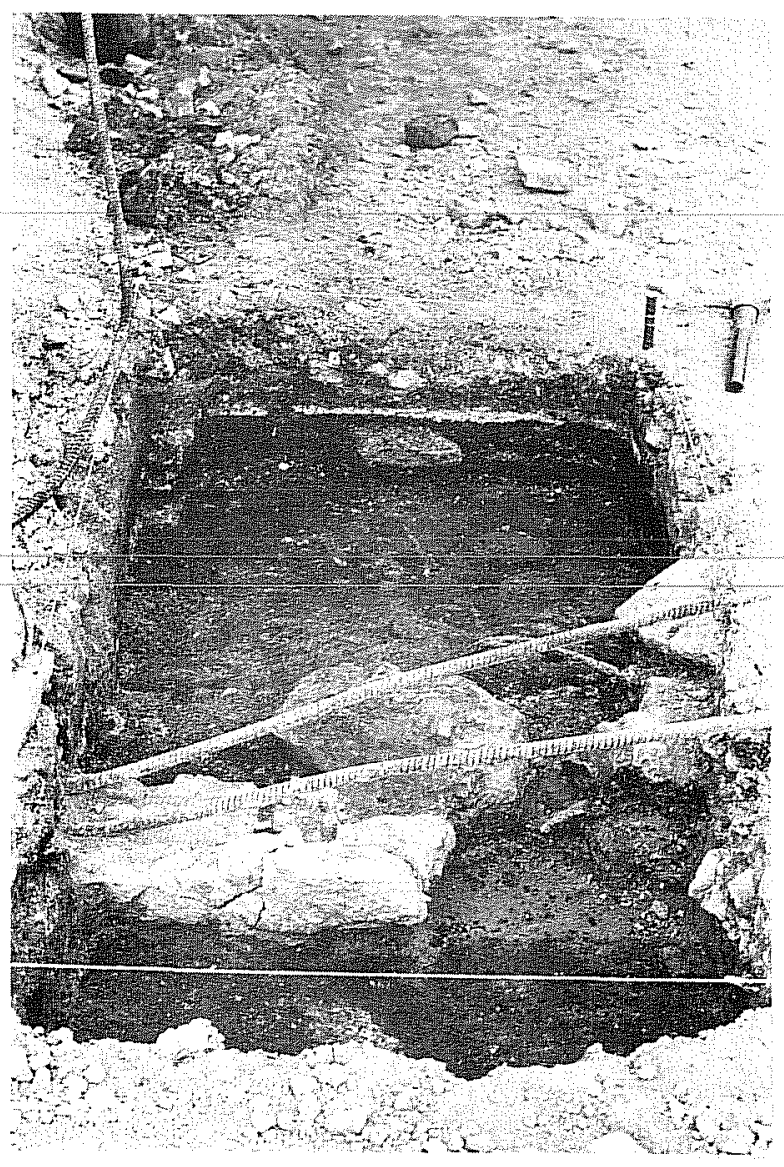

a

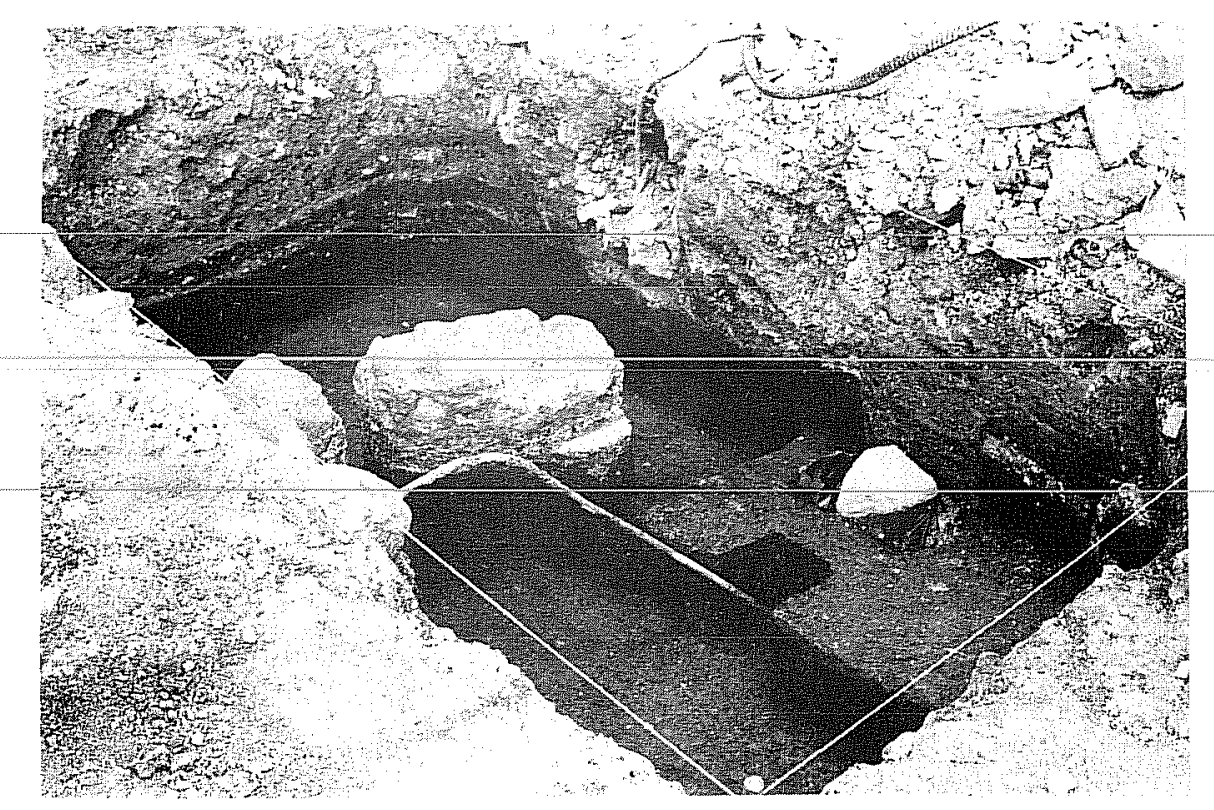

b

Figure 8. Photographs of Excavation A. a, looking southeast at $45 \mathrm{~cm} ; \mathrm{b}$, looking west at $60 \mathrm{~cm}$. 

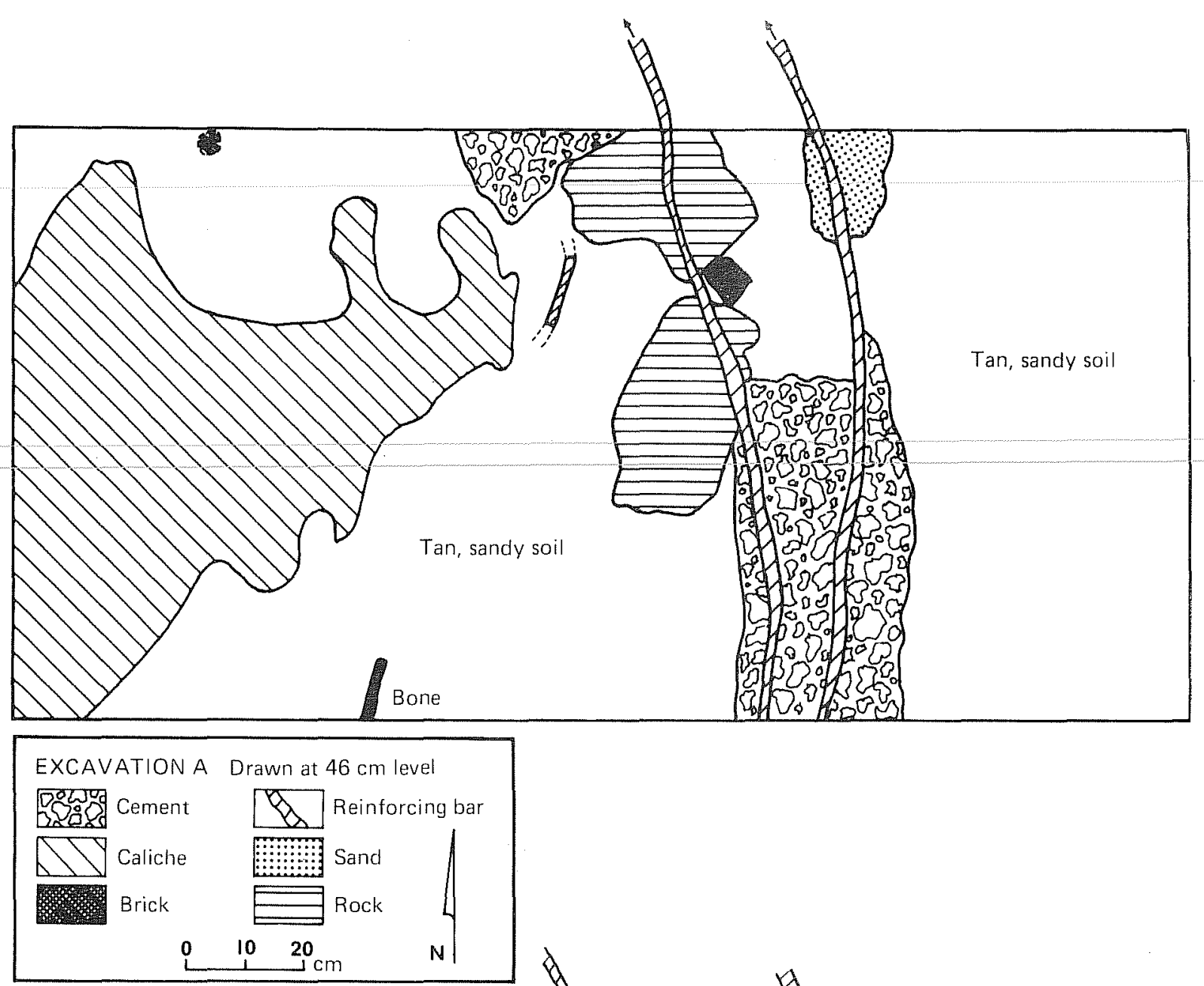

Dark brown, compact soil, nearly sterile Some charcoal \& bone fragments
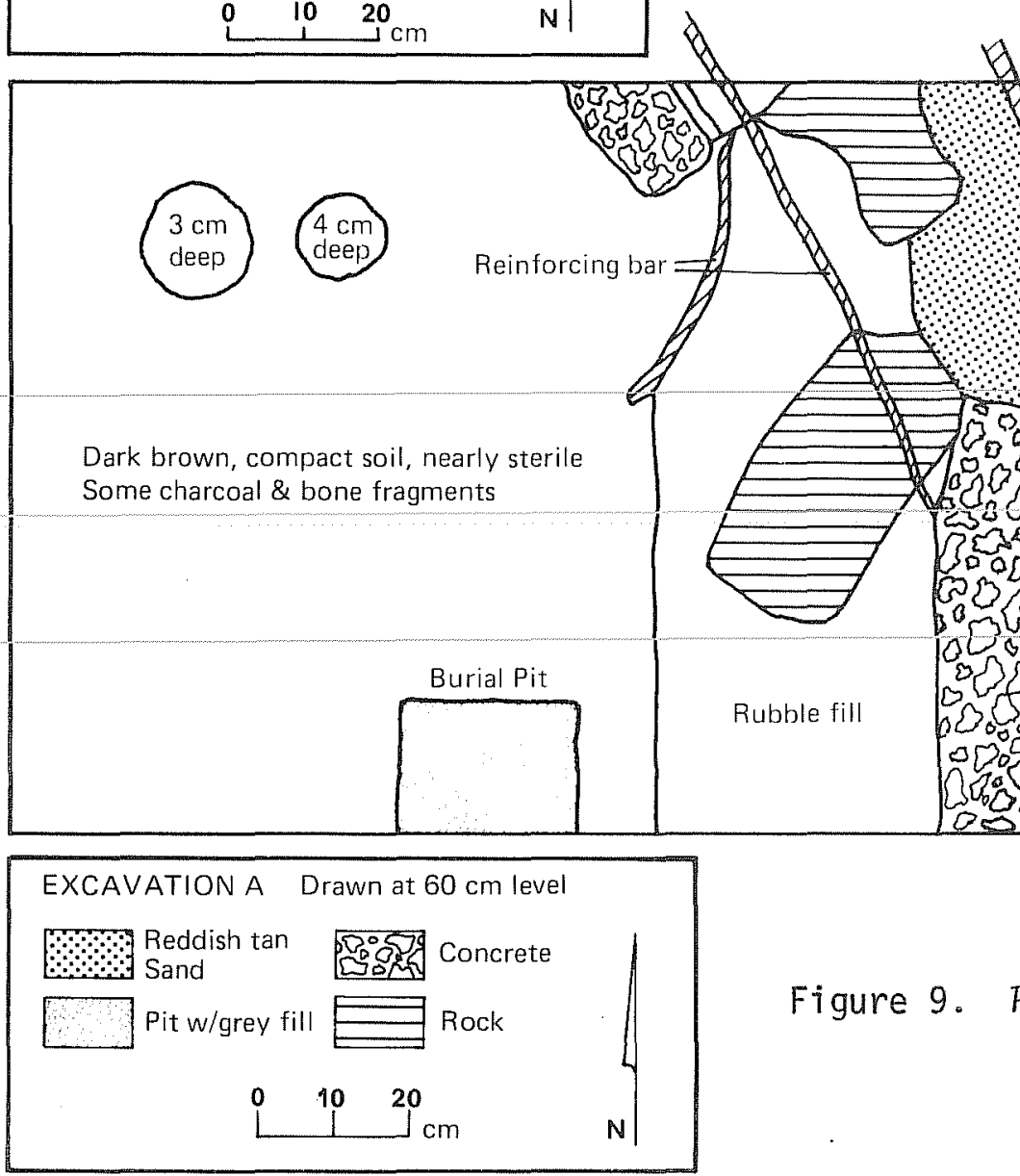

Figure 9. Plans of Excavation A. 

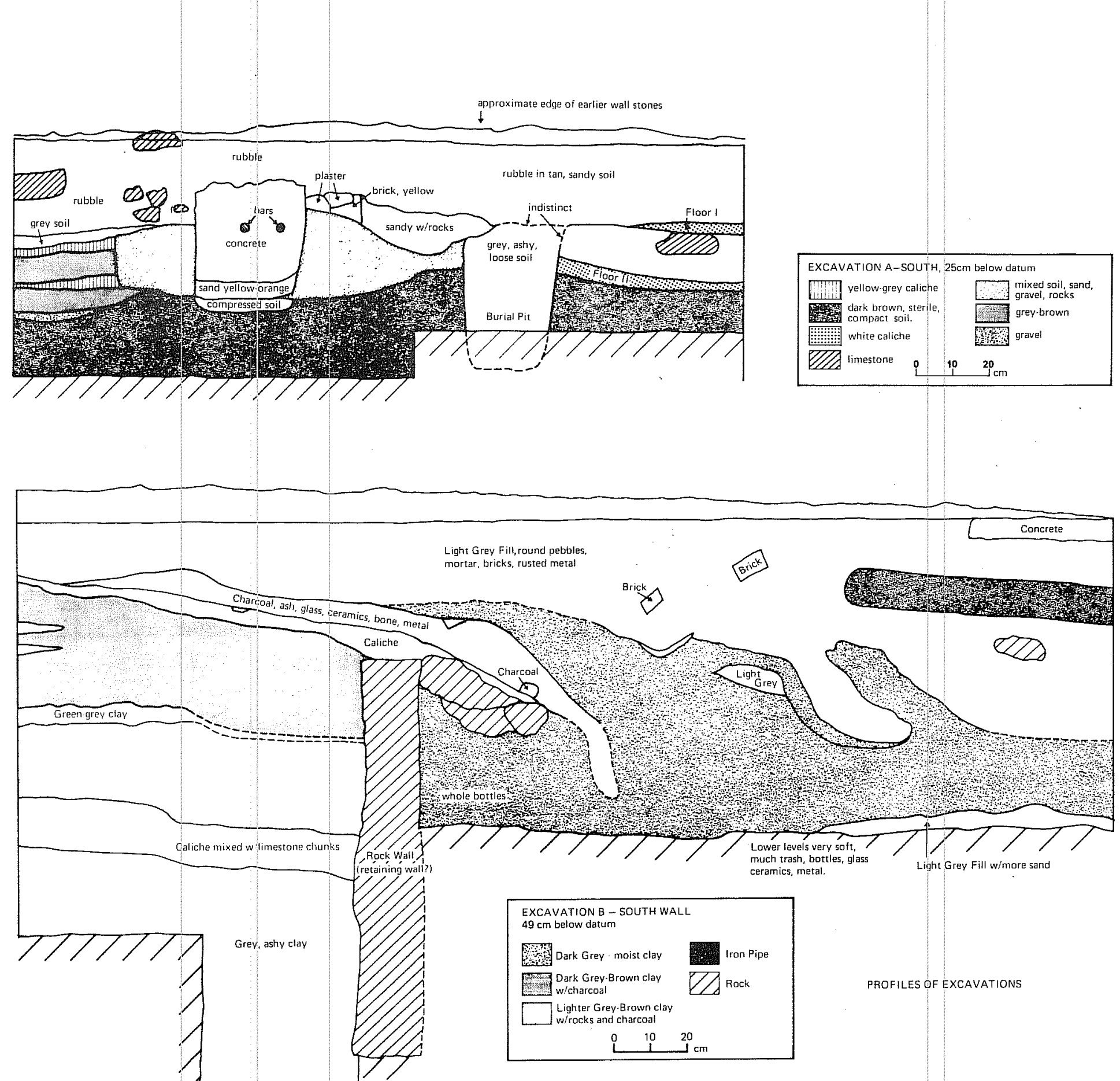

Figure 10. Profiles of Excavations $A$ and $B$. 


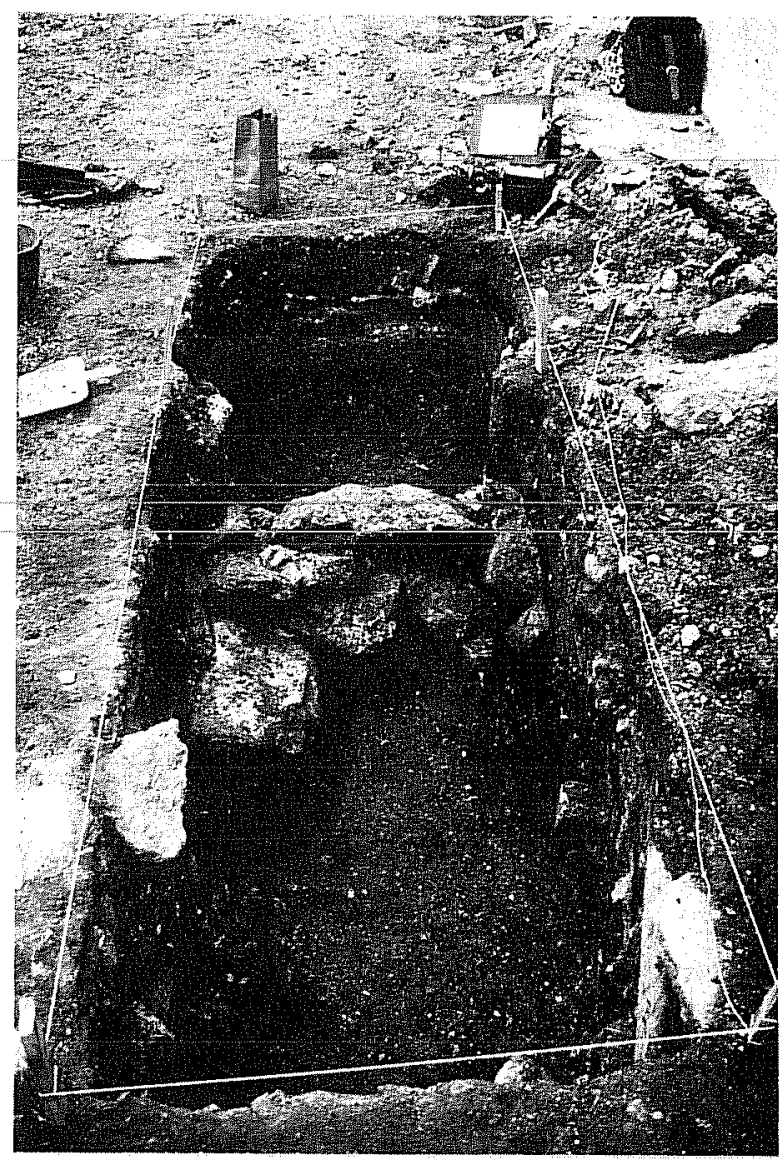

a

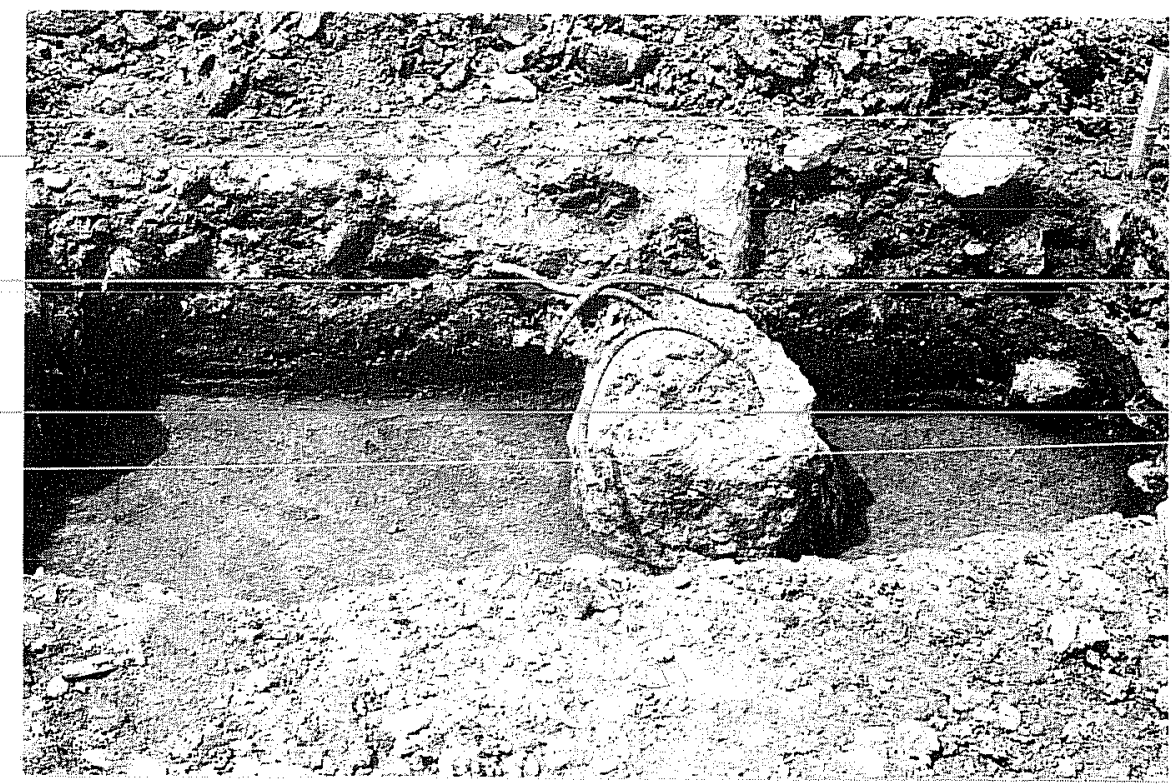

b

Figure 11. Views of Excavations $B$ and $C$. a, Excavation $B$ from the west, showing stratification in Colonial deposits east of the foundation wall; b, Excavation $C$ from the south showing reinforced concrete footing and absence of Spanish structural remains. 

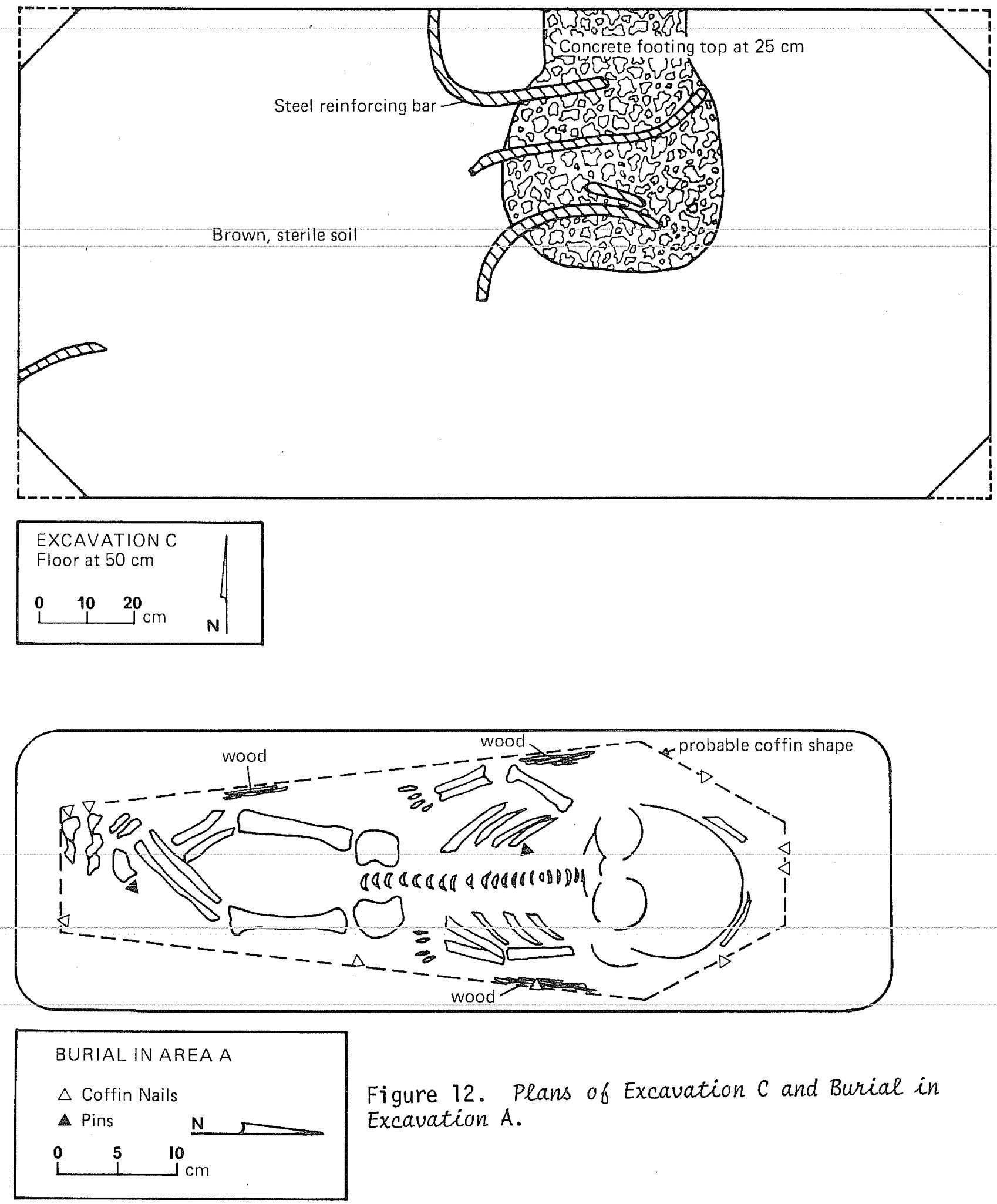

Figure 12. Plans of Excavation $C$ and Burial in Excavation A. 
Figure 13. Artifacts from Governor's Palace Park. Nineteenth Century Ceramics:

a. Decorated ironstone

b. Transfer decorated earthenware, blue

c. Transfer decorated earthenware, green

d. Mocha ware, shades of brown and cream

e. Shell edge, blue

f. Spattered and hand-painted, blue, green and rose

g. Spattered, rose

h. Hand painted, green, red and biack

i. Sponged luster ware, pink

j. Brown glazed stoneware 

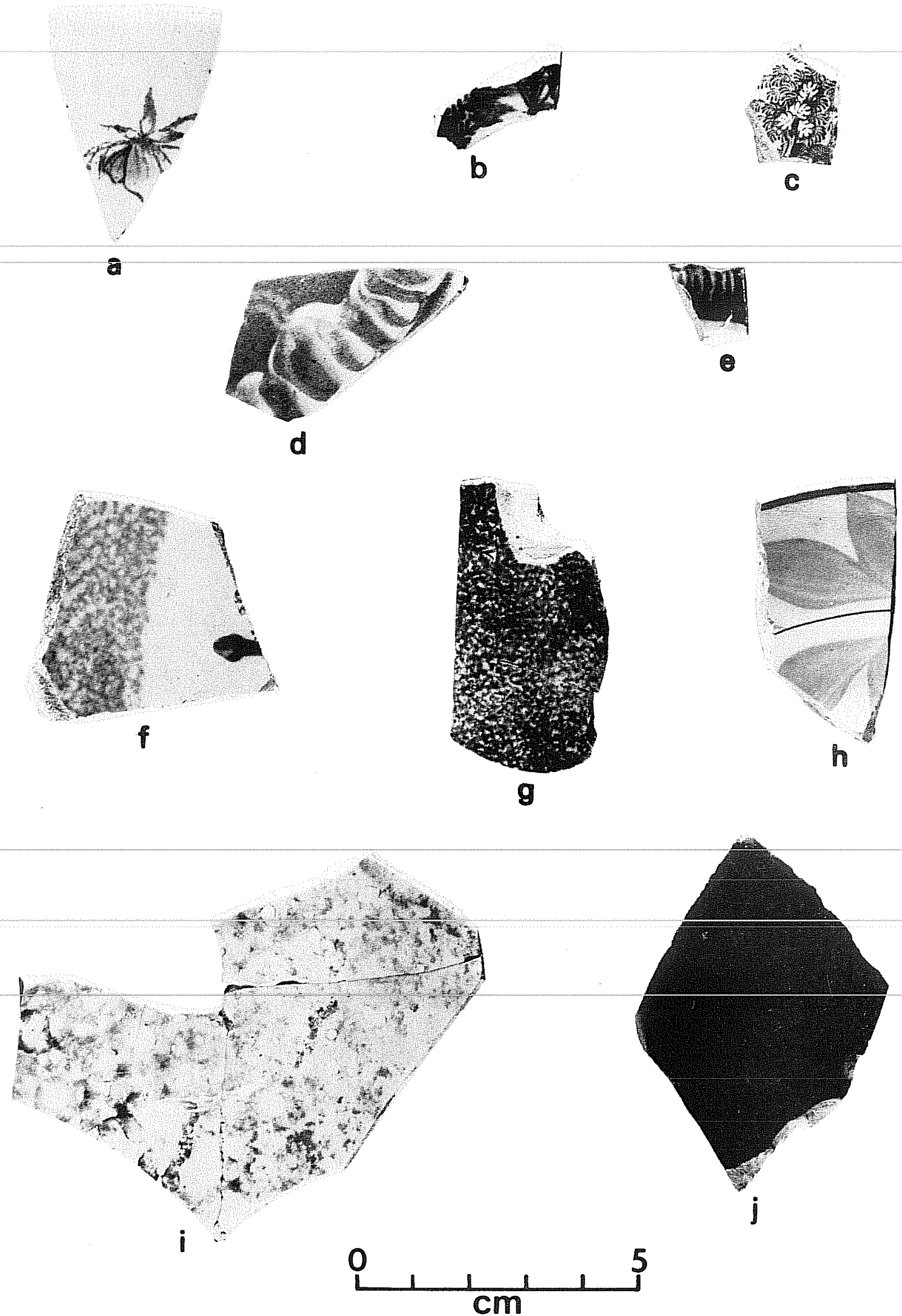
Figure 14. Artifacts from Governor's Palace Park.

Eighteenth Century Earthenwares:
a. Red-brown glazed ware
b. Goliad ware
c. Incised design on Goliad (?) ware
d. Goliad ware
e. Tonalá burnished ware
f. Red burnished ware
g. Tonalá burnished ware
h. Dlive jar
i. Decorated orange ware, black painted
j. Yellow glaze, impressed design
k. Red-brown glaze on red ware
1. Sandy paste utility ware 

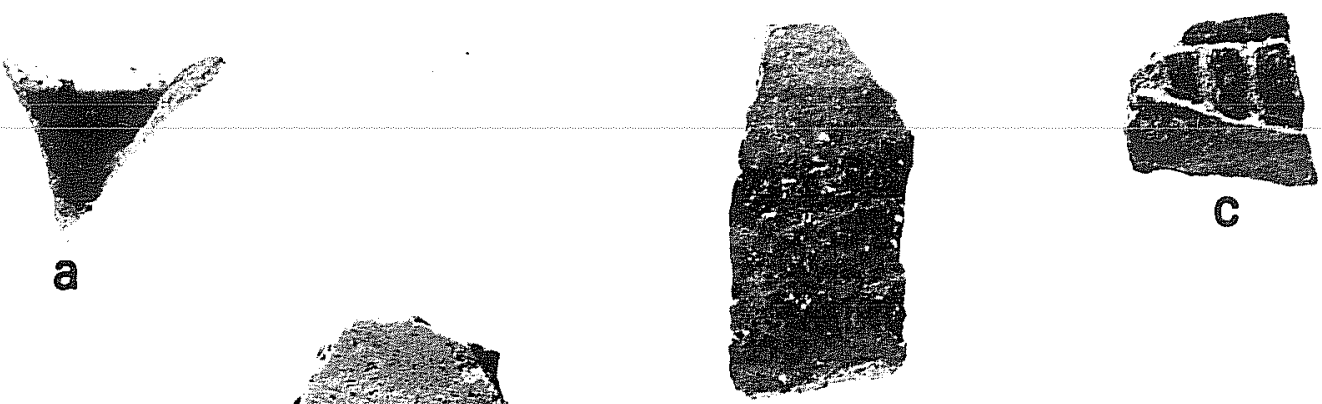

C

a

b
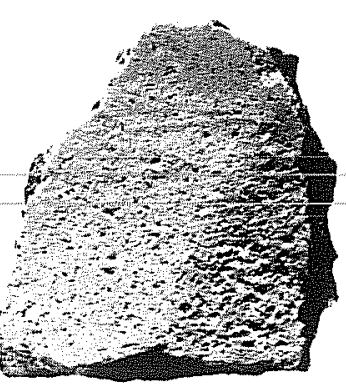

d
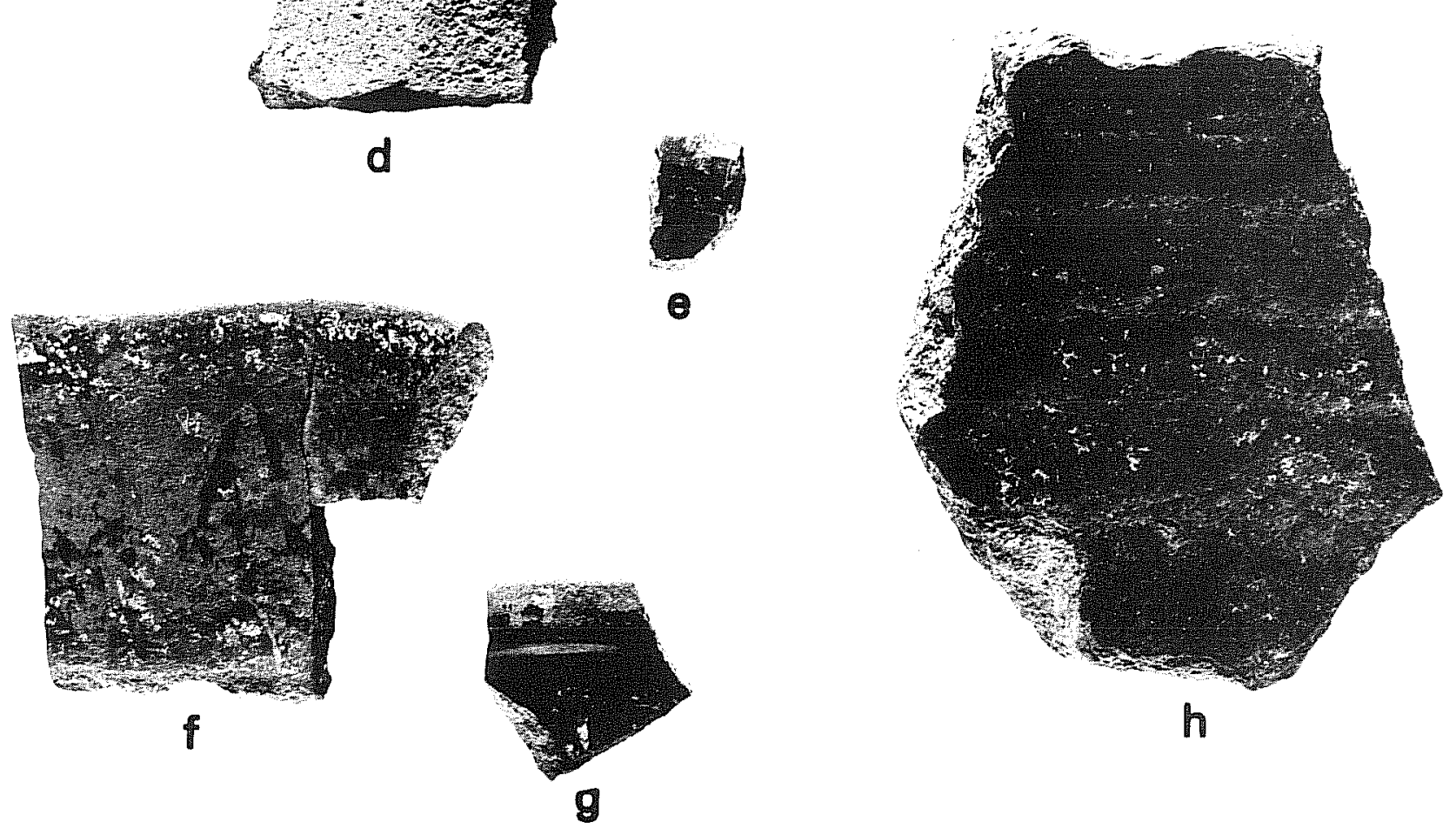

h

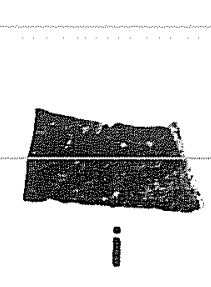

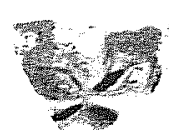
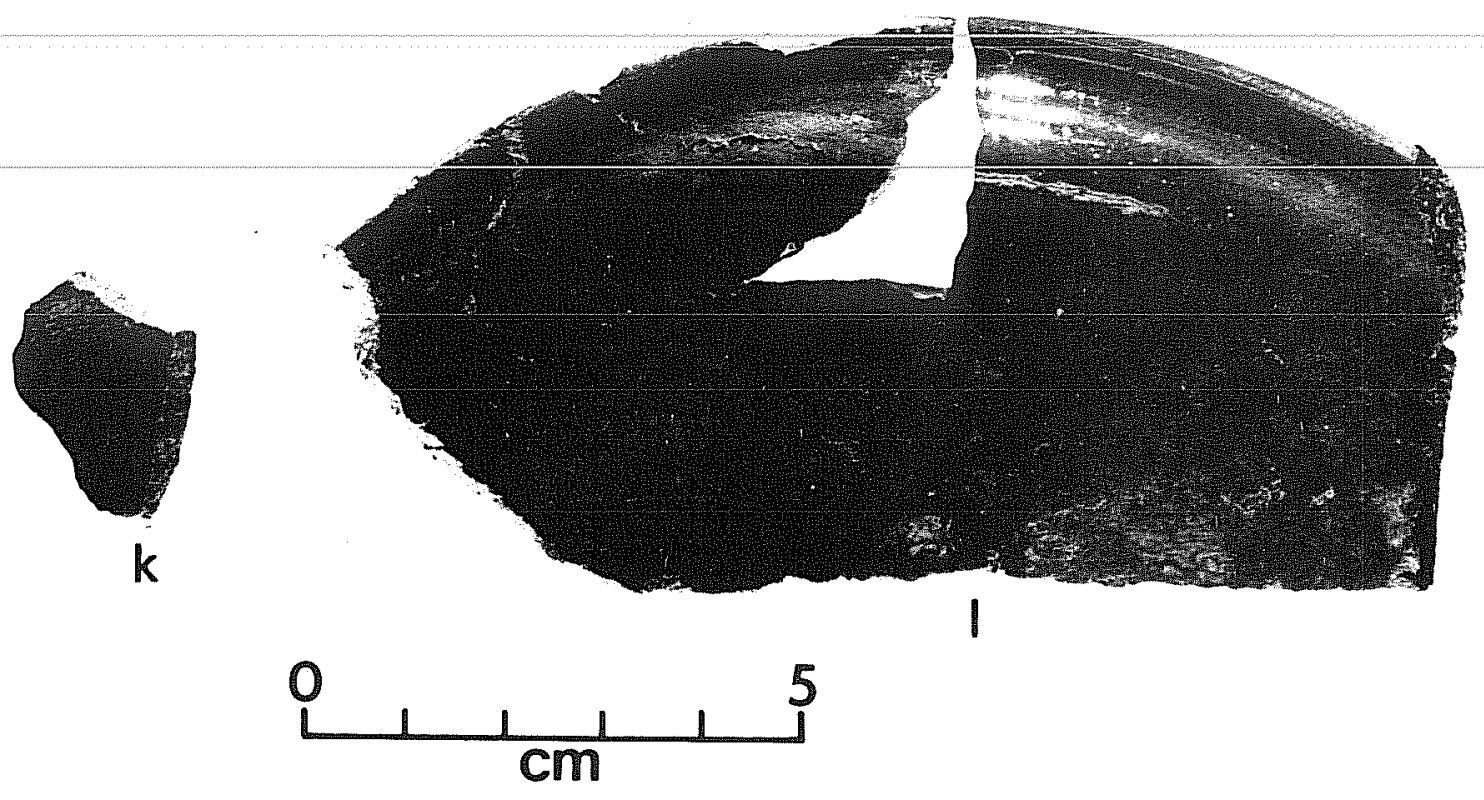
Figure 15. Artifacts from Governor's Palace Park. Eighteenth Century Majolica:
a. San Augustine Blue on White
b. Puebla Polychrome
c. Puebla Polychrome
d. Guanajuato
e. Huejotzingo Blue on White
f. Puebla BTue on White
g. White, undecorated
h. Puebla Blue on White 

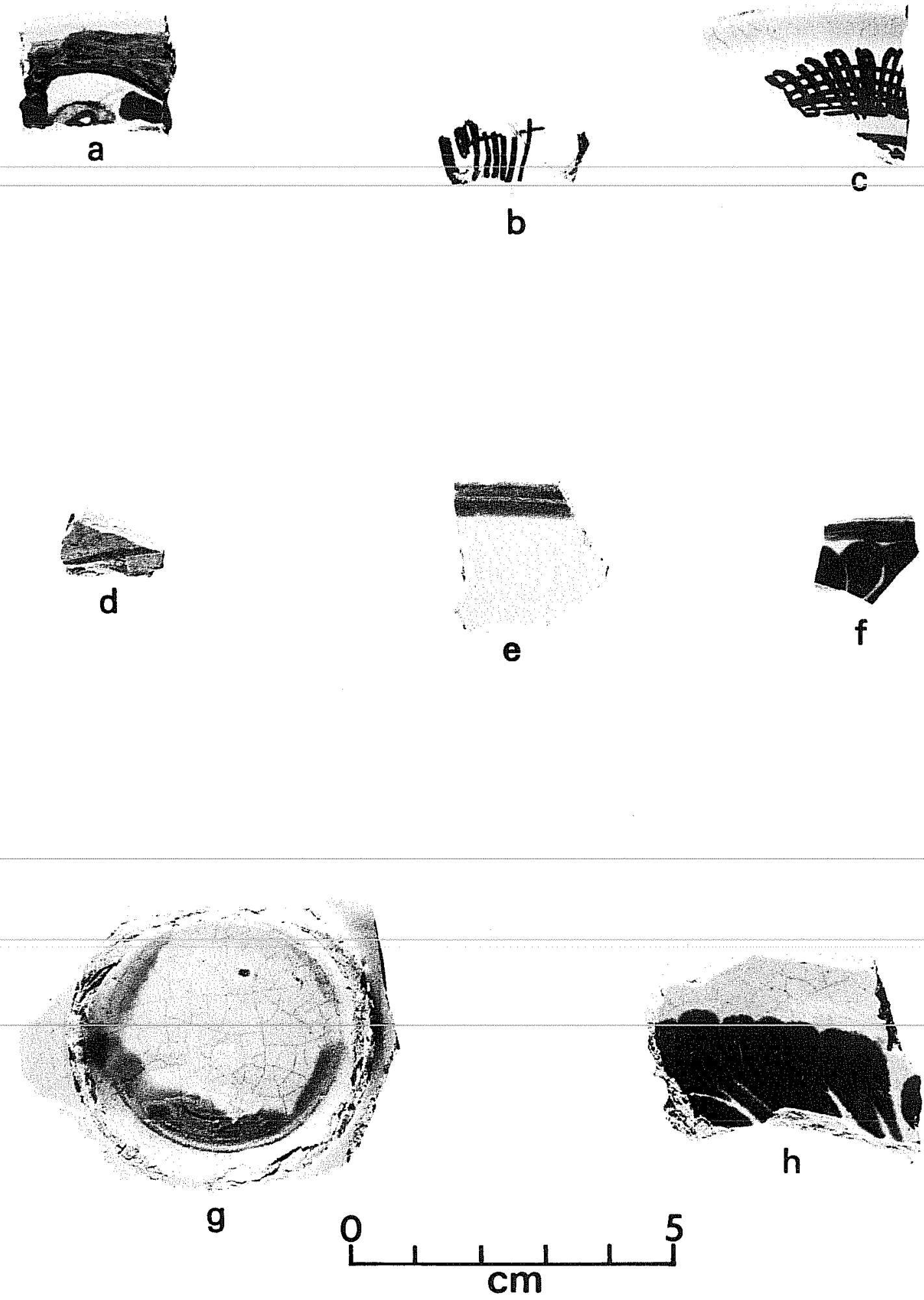
Figure 16. Artifacts from Governor's Palace Park. Metal and Stone:
a. Brass straight pin
b. Thin brass or copper fragment
c. Chain link fragment
d. Buckle fragment
e. Utilized quartzite flake
f. Utilized chert flake
g. Utilized chert flake 

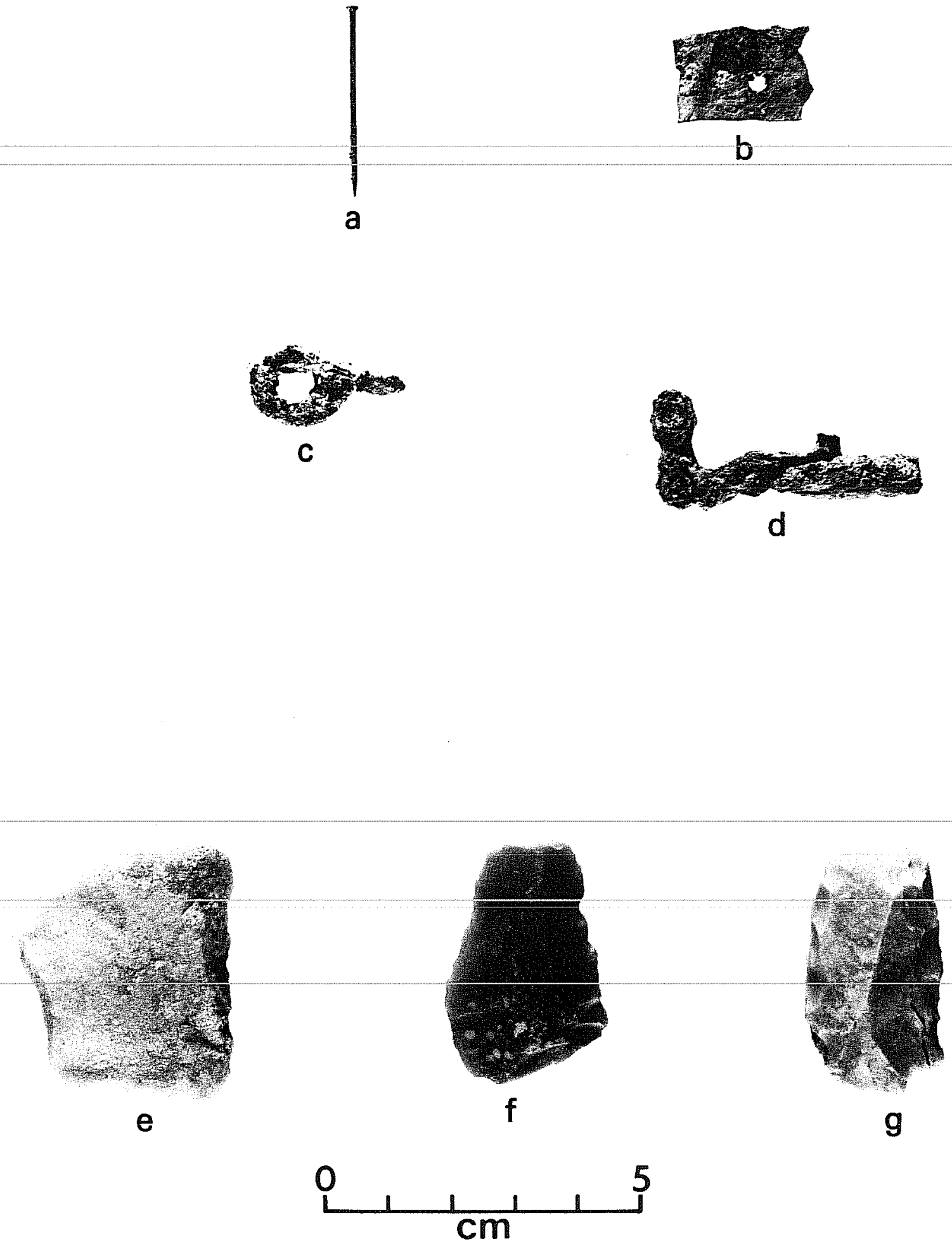


\section{REFERENCES CITED}

Bass, William M.

1971 Human Osteology: A Laboratory and Field Manual of the Human Skeleton. Missouri Archeological Society, Columbia.

Buckley, Eleanor Claire

1917 The Aguayo Expedition into Texas and Louisiana, 1719-1722 Quarterly of the Texas State Historical Association XV(1):1-65.

Chabot, Frederick $C$.

1929 Presidio de Texas at the Place Called San Antonio. San Antonio.

1931 San Antonio and Its Beginnings. Naylor, San Antonio. Corner, WiTliam

1890 San Antonio de Bexar. Bainbridge and Corner, San Antonio. Davis, William B.

1960 The Mammals of Texas. Department of Wildlife Management, Texas A \& M College, Bulletin 47.

Fairbanks, Charles H.

1973 The Cultural Significance of Spanish Ceramics. Ceramics in America, edited by Ian M. G. Quimby. The University Press of Virginia:141-174.

Forrestal, Rev. Peter P., translator

1934 Peña Diary of the Aguayo Expedition. Preliminary Studies of the Texas Catholic Historical Society. Austin.

Fü, Anne Adams

1974 Lead Glazed Wares. In: Mission Rosario Archeological Investigations 1973. Tevas Parks and Widdoife Department, Historic Sites and Restoration Branch, Archeological Report $14(1): 55-60$.

Fox, Anne A., Feris Bass, Jr., and Thomas Hester

1976 The Archaeology and History of Alamo Plaza. Center for Archaeological Research. The University of Texas at San Antonio, Archaeological Survey Report 16. 
Fox, Daniel E., John Clark, and Dan Scurlock

1977 Archeological Investigations at San Fernando Cathedra 1: A Preliminary Report. Office of the State Archeologist Special Report 22.

Gerald, Rex E.

1968 Spanish Presidios of the Late Eighteenth Century in Northern New Spain. Museum of New Mexico Research Records 7.

Gilmore, Kathleen

1974 Mission Rosario, Archeological Investigations 1973. Texas Parks and Wildlife Department, Historic Sites and Restoration Branch. Archeological Report 14(1).

Godden, Geoffrey A.

1964 Encyclopaedia of British Pottery and Porcelain Marks. Bonanza Books, New York.

1971 The Illustrated Guide to Mason's Patent Ironstone China and Related Wares. Praeger Publishers, New York.

Goggin, John M.

1964 The Spanish 01ive Jar. Indian and Spanish Selected Writings. University of Miami Press, Coral Gables, Florida.

1968 Spanish Majolica in the New World. Yale University Publications in Anthropology 72.

Greer, John W.

1967 A Description of the Stratigraphy, Features and Artifacts from an Archeological Excavation at the Alamo. State Building Commission Archeological Program, Report 3.

Habig, Marion A.

1968 The Alamo Chain of Missions. Franciscan Herald Press; Chicago.

Hatcher, Mattie Austin, translator and editor

1935 Letters of Antonio Martinez, the Last Spanish Governor of Texas, 1817-1822. Southwestern Historical Quarterly XXXIX:66-72, 139$147,228-238,327-332$.

James, Vinton Lee

1938 Frontier and Pioneer Recollections of Early Days in San Antonio and West Texas. Artes Graficas Press, San Antonio. 
Johnson, Francis E.

1962 Growth of the Long Bones of Infants and Young Children at Indian Kno11. American Journal of Physical Anthropology 20:249-254.

Kenda11, Dorothy Steinbomer, and Carmen Perry

1974 Gentilz, Artist of the old Southwest. University of Texas Press, Austin.

King, Ben, Jr.

1975 Curiosity finds palace original. San Antonio Express, March 15. Koch, Augustus

1873 Birds Eye View of the City of San Antonio. Map, Daughters of the Republic of Texas Library.

1886 Birds Eye View of San Antonio, Bexar County, Texas. Map, Daughters of the Republic of Texas Library.

Kovel, Ralph M. and Terry H. Kovel

1971 Dictionary of Marks, Pottery and Porcelain. Crown Publishers, Inc., New York.

Lister, Florence C. and Robert H. Lister

1975 Non-Indian Ceramics from the Mexico City Subway. EL Palacio, $81(2): 25-48$.

Martin, Etta

1931 San Antonio Restores Ancient Palace of Spanish Governors. Pan American, March:187-193.

Menchaca, Luis Mariano

1803 U1tima Voluntad Testamentaria de Luis Mariano Menchaca. Bexar Archives. Library of the University of Texas, Archives Division, Austin.

Morfi, Juan Augustin

1935 History of Texas. Translated and annotated by Carlos Castaneda. The Quivira Society, Albuquerque.

Rams de 11, Charles

1959 San Antonio, A Historical and Pictorial Guide. The University of Texas Press, Austin. 
Raycraft, Don and Carol Raycraft

1975 American Country Pottery. Wallace-Homestead Book Company, Des Moines, Iowa.

Schour, Isaac and M. Massier

1947 The Development of the Human Dentition. Journal of the American Dental Association 28:1753-1160.

Schuetz, Mardith $K$.

1968 Historical Documentation and Description of the Structures. The History and Archeology of Mission San Juan Capistrano, San Antonio, Texas I. State Building Commission Archeological Program, Report 10.

1969 Description of the Artifacts and Ethno-History of the Coahuiltecan Indians. The History and Archeology of Mission San Juan Capistrano, San Antonio, Texas II. State Building Commission Archeological Program, Report 11.

1974 The Dating of the Chape 7 at Mission San Juan Capistrano, San Antonio, Texas. Texas Historical Commission, Office of the State Archeologist, Special Report 12.

Snow, David $H$.

1965 The Chronological Position of Mexican Majolica in the Southwest. El Palacio 72(1):25-35.

Spanish Archives, Bexar County Courthouse

1804 Sale of a Stone House by Jose Manchaca to Ygnacio Perez. Vol. E2:75-76.

Taylor, Virginia H., translator and editor

1957 Calendar of Letters of Antonio Martinez, 1817-1822. Southwestern Historical Quarterly LII:387-400; 533-547. 